\title{
Bijdrage tot de historische geografie van de streek rondom Brugge
}

door

\author{
M. COORNAERT
}

\section{INLEIDING}

Het vorsen naar de vorming en de bewoning van de Vlaamse kustvlakte is vele jaren geleden begonnen. De vroegere vorsers hebben weinig positieve resultaten bereikt, o.a. door de onvoldoende kennis van de oudste bronnen of door gebrekkige interpretatie. De grootste hindernis was echter het feit dat men onwetend stond tegenover de geschiedenis van de bodem. Omdat de fazen van de poldervorming niet gekend waren, had men het moeilijk om de fazen van de landwinning en de bewoning vast te leggen.

J. Ameryckx en R. Tavernier hebben de grote stap gezet waardoor de verantwoorde studie van de kustvlakte kon aanvangen. Hun onderzoek van de bodem heeft uitgemaakt in welke perioden de zee de poldergrond aangeslibd heeft en in welke eeuwen de bewoning van diezelfde grond mogelijk werd.

Steunend op hun bevindingen hebben verschillende zoekers de historische geografie van een onderdeel van de Vlaamse kustvlakte aangepakt. Van de hand van Prof. A. Verhulst verschenen een paar werken over de streek ten noorden van Brugge. De historische geografie van West-Zeeuws-Vlaanderen werd door Dr. M. Gottschalk bekend gemaakt. R. Boterberghe heeft de inpoldering van de IJzervlakte behandeld. Ondergetekende heeft een stuk van het zg. Middelland ten noorden van Lissewege en Dudzele onderzocht.

Doch geen enkele van de bovengenoemde schrijvers zal beweren dat zijn onderwerp volledig uitgeput is, en dat al zijn bevindingen onomstotelijk vaststaan. Voordat men de volledige geschiedenis van de Vlaamse Polders kan opstellen, moeten ontelbare geschreven bronnen bewerkt worden en moet veel werk op het terrein verricht worden. Het gedetailleerde onderzoek is een allereerste vereiste om tot een goede kennis van gans de polderstreek te komen.

Een volgende stap in de goede richting is het jongste werk van Prof. A. Verhulst. Daarin vat hij de rezultaten samen, die tot dusverre door hemzelf en door anderen bereikt werden, o.a. wat betreft de studie van de

\section{AFKORTINGEN :}

ABB : Archief Bisdom Brugge.

RAB : Rijksarchief Brugge.

ASB : Archief Seminarie Brugge.

SAB : Stadsarchief Brugge. 
Vlaamse Polders. Doch juist omdat de laatstgtıoemde studie nog ver van beëindigd is, zijn in het bedoelde werk bepaalde punten nog niet onder ogen genomen of onvoldoende uitgewerkt.

Het weze ons dan toegelaten in de onderhavige hoofdstukken enkele aanvullingen te geven of zelfs enkele andersluidende meningen te uiten. $\mathrm{Bij}$ het schrijven van ons artikel zullen we zoveel mogelijk van nog onbekende archief teksten en van waarnemingen ter plaatse uitgaan.

\section{DE SCHORRETIJD}

De belangrijkste en de meest uitgebreide polderlaag is door de Duinkerke II-transgressie aangebracht. Aangeslibde grond heette „scor" of ,anwerp". Naarmate de schorre zich uitbreidde en begroeid geraakte, werd ze door boeren uit de Zandstreek als schapenweide in gebruik genomen. Het schorreland werd steeds breder en de afstand tot de Zandstreek langer. Het enige middel om het vee en zijn herder tegen een verrassend hoge vloed te beschermen, was het opwerpen van een vluchtheuvel.

Tot voor kort waren in de Vlaamse Polders zeer weinig terpen bekend. We noemen slechts Kathem te Dudzele en Ten Doele te Oostkerke. Uit dit feit mag men echter niet besluiten dan onze kustvlakte niet, zoals b.v. Friesland, door middel van vluchtbergen bezet was.

Drie jaar geleden zijn we begonnen, met behulp van landboeken en andere dokumenten, het land achter de Evendijk te onderzoeken. Dit grondige vorsingswerk heeft dadelijk geleid tot de ontdekking, dat op een oppervlakte van ong. $10 \mathrm{~km}^{2}$ nog zes vluchtheuvels aanwezig zijn. Een terp wordt in een middeleeuws landboek ,hooghe wal" genoemd. Vier van de aangehaalde wallen hebben middelmatige afmetingen, d.w.z. ca. $35 \mathrm{~m}$ bij ca. $40 \mathrm{~m}$. De overige twee werden nog in de schorretijd uitgebreid, en zijn uitgegroeid tot een woonkern, en na de indijking tot een dorp, nl. Koudekerke en Ramskapelle.

Een aantal van de bedoelde terpen liggen in een rij, die vanuit het zuidwesten naar het noordoosten loopt. Dit feit maakt het duidelijk dat een stuk van het Middelland vanuit Lissewege door middel van vluchtheuvels in gebruik genomen is. Het noordelijkste punt van de aangehaalde terpenrij is het dorp Koudekerke ${ }^{1}$.

We kunnen nog geen vaste gegevens brengen over het gebied, dat grenst aan de door ons onderzochte sektor. Toch zijn we er zeker van dat ook in de ambachten Oostkerke en Dudzele een redelijk aantal wallen te vinden zijn.

Het grondgebied van de Blankenbergse Watering ligt historio-geografisch gezien nog braak. Voor zover we weten heeft men op het terrein nog geen enkele terp ontdekt. Maar waarom zouden niet in deze streek vluchtbergen opgeworpen zijn, om de uitbating en de bewoning mogelijk te maken? De afstand van de Zandstreek tot de zee bedraagt immers $\pm 12 \mathrm{~km}$.

Inderdaad, een oppervlakkige lezing van de ommeloper van de Blan-

(1) M. Coornaert, Het Land achter de Evendijk, in Rond de Poldertorens, Se jg. nr. 4 p. 135 (1963). 
kenbergse Watering stelt ons reeds in kennis met een paar vluchtheuvels. We vermelden slechts de "hooghe wal", die even ten westen van het dorp Wenduine gelegen was ${ }^{2}$. Een nauwkeurig onderzoek, zowel van de landboeken, als van het terrein, zal zeker een aantal „hoge” wallen opleveren.

De bezichtiging van het terrein heeft ons geleerd dat Ramskapelle, Koudekerke en Uitkerke op een grote woonterp gevestigd zijn. Bij een bezoek aan de dorpen Houtave, Vlissegem en Nieuwmunster merkt men dadelijk dat de grond, waarop de kerk en de aanpalende huizen staan, ongeveer een meter hoger ligt dan de omliggende polder.

$\mathrm{Er}$ is echter een omstandigheid, die het zoeken naar terpen zal beperken, nl. het feit dat langs de zeezijde een brede strook grond verloren gegaan is door het opdringen van de zee of door duinverstuiving.

\section{DE EERSTE LANDWINNINGEN}

Het uitgestrekte schorreland langs de Vlaamse kust was in de $10 \mathrm{e}$ eeuw helemaal in gebruik als schapenweide. Waarschijnlijk waren enkele vluchtheuvels ingericht als woonplaats. Ongetwijfeld zagen de uitbaters van het schorreland al lang de noodzakelijkheid om hun weiden, hun kudden en eventueel hun woningen blijvend tegen de zee te beschermen.

Twee grote gebieden werden door een dijk veilig gesteld, het eerste door de Oude Zeedijk, van Lo tot de zee ${ }^{3}$, het tweede door een andere dijk, waarvan we nu de loop zullen volgen. Hij makt een wijde boog, waarvan beide uiteinden bij de naaste rug van de Zandstreek aansluiten.

Het oostelijke uiteinde ligt te Brugge. Langs de Vlamingdam en de Groene Straat bereikt de dijk St.-Pieter-op-de-Dijk. Aangezien de bedoelde sektor reeds vroeg vervallen geraakt is, kan men de breedte en de hoogte ervan niet meer bepalen. Ten noorden van St.-Pieter is het dijkterrein over een afstand van $\pm 10 \mathrm{~km}$ nog goed bewaard. De rug is nergens nog meer dan een halve meter hoog. Tussen St.-Pieter en Zuienkerke is de dijk 21 tot $24 \mathrm{~m}$ breed. De grootste breedte ligt ter hoogte van St.-Jan-op-de-Dijk: ong. $30 \mathrm{~m}$. Bij de Kuiperscheidweg wordt het weer $25 \mathrm{~m}$. Ten noorden van de genoemde weg is de overbreedte van de dijk, langs de rijweg, reeds lang verkocht en in de aanpalende velden opgenomen. Dit stuk is $500 \mathrm{~m}$ lang.

Verder noordelijk versmalt de dijk tot $12-14 \mathrm{~m}$. Ten westen van Uitkerke is deze smallere sektor, over een afstand van $600 \mathrm{~m}$, door de Duinkerke - III A-transgressie weggespoeld (1e helft elfde eeuw). De bodemkaart toont inderdaad overslaggrond achter de bres ${ }^{4}$. De oudste dijk is vervangen door een lange vingerling, die $\pm 10 \mathrm{~m}$ breed is.

Thans moeten we spreken over de naam van de beschreven dijk. Het kapittel van St.-Donaas bezat een groot aandeel in het tienderecht van gans het ambacht Uitkerke. Het deel ten westen van de dijk heette West-overde-Dijk, het deel ten oosten Oost-over-de-Dijk. De oudste verwijzing naar

(2) RAB, Blank. Watering, nr. 441, Ommeloper, fo $591 \mathrm{v}^{\circ}$ (1617).

(3) Dr. A. Verhulst, Het Landschap in Vlaanderen, p. 19.

(4) J. Ameryckx, Bodemkaart België, kaartblad $10 \mathrm{E}$ Blankenberge (1952). 
deze termen dateert uit 1235: „,decime sue de Utkerka intra dicum westover" ${ }^{5}$. De naam van de dijk verschijnt in 1247: „, in parrochia Utkerka... in loco qui dicitur westover de ghentele" ${ }^{6}$.

Het volgende feit bewijst dat de Gentele wel degelijk een dijk is. Midden vijftiende eeuw besloot de Blankenbergse Watering de onderhoudswerken van de watering voor drie jaar uit te besteden. Een van de bepalingen van de overeenkomst was "de ghentele te houdene te ghereicx, deze drie iaren lanc gheduerende, dat $t$ varssche water, dat van oosten comt, te weerne ende buten der ghentele te houdene" " .

Het terrein ten noordwesten van Uitkerke is thans grotendeels bebouwd. Daarom werd het door de Dienst voor Bodemonderzoek niet bewerkt. Tengevolge daarvan heeft men gemeend dat de Gentele van eerst af aan naar het noorden doorliep. Hij buigt af naar het noodwesten en het westen. De oudstbewaarde ommeloper van de Blankenbergse Watering (1478) noemt deze noordelijke dijk, tussen Uitkerke en Wenduine, op verschillende plaatsen ontegensprekelijk „Evendyc” 8.

Dr. M. Gottschalk en wij hebben er reeds op gewezen dat de oudste zeedijken ten noorden van Brugge in de $11 \mathrm{e}-12 \mathrm{e}$ eeuw met de naam Evendijk aangeduid werden ${ }^{9}$. Volgens een charter bestond de Evendijk in de $13 \mathrm{e}$ eeuw nog te Bredene ${ }^{10}$. Te Uitkerke bestaat nog een stukje van de Evendijk; het is $18 \mathrm{~m}$ breed en het heet Landdijk. Te Blankenberge neemt de Vredelaan de ruimte van de dijk in. Hier lag een kleine vingerling. Het wiel in de bres heette Goezemaarsput (perceel C 191).

Ten westen van Wenduine is de Evendijk vóór 1400 overstoven geraakt. Ten noorden van Bredene buigt hij af naar het zuiden. Van hier tot Oudenburg is zijn naam Zidelinge. M. Gysseling geeft de oudste vermeldingen: silinga (1201); silinge (1222); sidelinghe (1223) ${ }^{11}$.

De dijklijn Gentele-Evendijk-Zidelinge is opgeworpen vóór het opkomen van de Duinkerke III A, bijna zeker vóór het jaar 1000. Blijkens zijn formaat en zijn naam Evendijk was de bedoelde dijk geen „kadedijkje”. We menen te mogen besluiten dat het opwerpen van dijken met de afmetingen van een zeewering in de $10 \mathrm{e}$ eeuw begonnen is.

Men mag immers niet vergeten dat het dorp Klemskerke, dat in de Blankenbergse Watering slechts $3 \mathrm{~km}$ van de zee verwijderd ligt, in 1003 vermeld wordt ${ }^{12}$. Dit betekent dat het dorp reeds enkele jaren vóór 1000 belangrijk genoeg was om een kerkje te krijgen en parochie te worden. Welnu, we kunnen niet aannemen dat in een poldernederzetting dicht bij de zee een kerkje gebouwd werd, zolang de omringende grond niet tegen de zee gevrijwaard was.

(5) ABB, Reeks A nr. 127, Cartularium St.-Donaas, fo $117 \mathrm{v}^{\circ}$ (1235).

(6) Idem, $f^{\circ} 122 \mathrm{r}^{\circ}(1247)$.

(7) Kommissie Openbare Onderstand Brugge, Arch. St.-Janshosp. A 10, Blank. Wat. rol (ong. 1440).

(8) Blank. Wat. nr. 406, Omm. $f^{\circ} 304 \mathrm{v}^{\circ}$ en $306 \mathrm{r}^{\circ}$ (1478).

(9) Dr. M. Gottschalk, Hist. Geografie West-Zeeuws-Vlaanderen, 1, p. 4 (1955).

(10) RAB, Charter blauw nummer 4399 (1281).

(11) Dr. M. Gysseling, Toponymie van Oudenburg, p. 232 (1950).

(12) R. Boterberge, Hist. Geografie van het IJzerestuarium, in Hand. Gesch. Gent, Deel 16, p. 83 (1962). 
Vooral het bestaan van Klemskerke verplicht ons de aanleg van de Evendijk in de tweede helft van de 10e eeuw te stellen. Ook M. Gottschalk plaatst de bouw van de Evendijk in het Ambacht Oostburg ca 1000. Ze wijst tevens op het bestaan van de plaatsen Tubindic in 1025 en Isendijke in $1046^{13}$.

Men kan opwerpen dat de oudste dijklijn van de Blankenbergse Watering in de noordoosthoek twee breuken vertoont, en dat ook de verdwenen sektor doorbraken zal gekend hebben. Toch bewijst dit alles niet dat de bedoelde dijk veel zwakker was dan de latere zeedijken. Ook deze laatste hebben breuken meegemaakt en konden niet altijd de zee tegenhouden.

Ten noorden van de Evendijk lag nog een strook schorre, die $1 / 2$ tot $1 \mathrm{~km}$ breed was. Deze werd door een volgende zeedijk gewonnen, misschien vóór de Duinkerke III A. De tweede zeedijk takt af van de Evendijk ten noordwesten van Uitkerke. We kennen niet zijn oorspronkelijke naam. Later heet hij Westdijk, thans Weststraat.

Langs de noordzijde is de dijk helemaal weggespoeld, samen met een strook polderland. $\mathrm{Bij}$ een andere gelegenheid hebben we, dank zij vele dokumenten van vóór 1500, kunnen berekenen hoeveel grond de Oudemaarspolder aan de zee en aan de duinen prijsgegeven heeft ${ }^{14}$. De breedte van de verlorene zone ligt tussen 200 en $250 \mathrm{~m}$. Het zeefront van de Blankenbergse Watering moet ong. evenveel meter geweken zijn.

Ten westen van Wenduine zijn reeds vóór 1400 ganse beginnen (sekties) van de Blankenbergse Watering met zand overdekt. De ommeloper van 1478 toont hoe ver het grondverlies gevorderd was. Het 71e begin, even ten noordwesten van de kerk van Wenduine was „al gheabandoneert ende vervloghen". Tussen Wenduine en Blankenberge worden nog resten van het $70 \mathrm{e}$ en $36 \mathrm{e}$ begin vermeld. Deze overblijvende grond, samen ong. $30 \mathrm{G}$ (1 gemet $=44$ aren) werd in de tweede helft van de $16 \mathrm{e}$ eeuw uitgedolven om de zeedijk te versterken. $\mathrm{Na} 1600$ bleef van de polder buiten de Evendijk slechts één begin over: het 35e met 147 gemeten; dit is de grond tussen de Vredelaan en de Weststraat te Blankenberge.

Op het einde van dit hoofdstuk hebben we het nog over een kleine polder. Deze ligt ten noordoosten van de Westdijk en beslaat slechts het $34 \mathrm{e}$ b. De gewonnen strook is juist breed genoeg om een nederzetting te bevatten. Waarschijnlijk heette de schorre vóór de inpoldering Scharphout. Het is in elk geval zeker dat de kerk van O.L.V. van Scharphout in de eerste helft van de veertiende eeuw, met de omringende woningen, voor de zee geweken is. De huidige St.-Antoniuskerk werd $600 \mathrm{~m}$ zuidelijker gebouwd. De graaf heeft het dorp binnen de Oostdijk al vroeg stadsrechten gegeven. Het rechtlijnig karakter van het stratennet van het oude Blankenberge wijst op een kunstmatig ontstaan.

Blijkbaar bezat de Heer van Gistel rechten op het aangeworpene land ten noorden van de Evendijk. Immers in de laatstgenoemde twee beginnen, het $34 \mathrm{e}$ en het $35 \mathrm{e}$, liggen enkele achterlenen van de Baronie van Gistel,

(13) M. Gottschalk, o.c., p. 19.

(14) M. Coornaert, De Zeewering van de Oudemaarspolder, in R.d.P., 8e jg., nr. 2 en 3 (1966). 


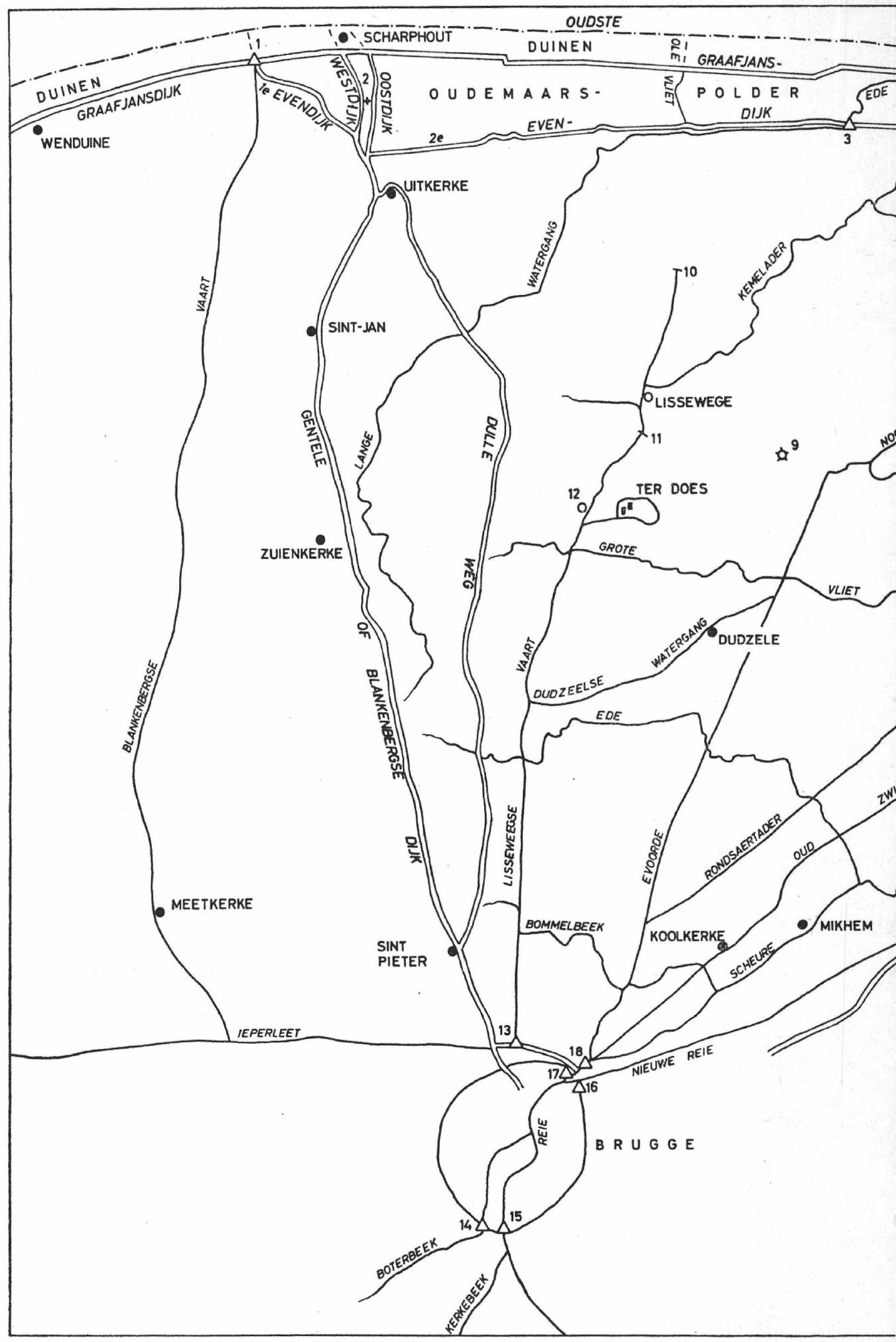

1. Sluis van Blankenbergse Watering - 2. Kerk van Blankenberge - 3. Boudin Meitins Sluis - 4. Eiesluis - 10. Zwankendamme - 11. Esinehoek - 12. Gizele - 13. Monnikenspeie - 14. Sluisje van Boterbeek - 15. Zwin - 19. Speie te Damme - 20. Speie van de Gentse Leie - 21. Sluisje te Lembeke - 22. Pylyzersdam. 


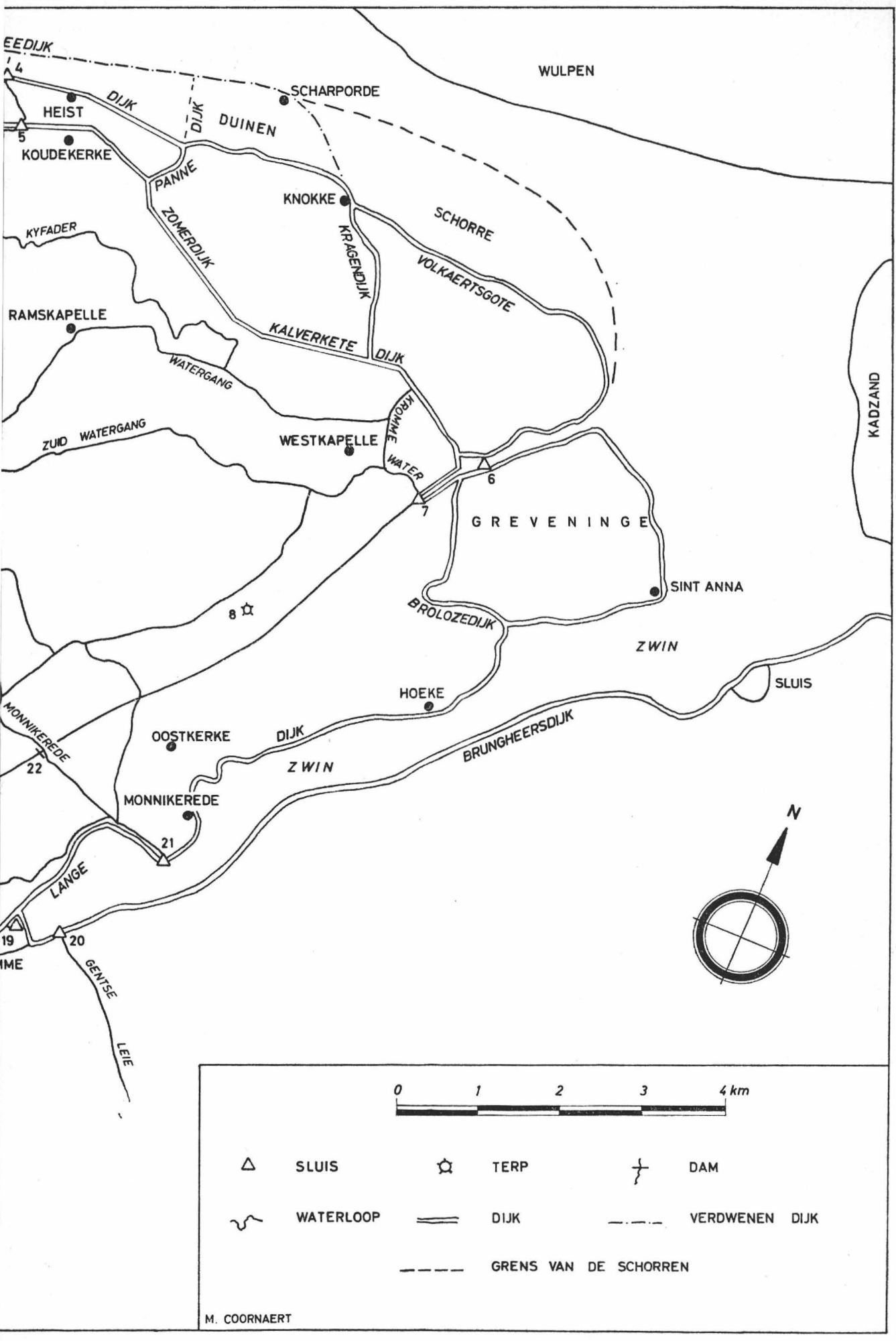

Koppesluis - 6. Sluis van Reigaarsvliet - 7. Kwintinssluis - 8. Ten Doele (terp) - 9. Kathem (Terp) iis van Minnewater - 16. Speie van Speipoort - 17. Sluisje onder Lenaartpoort - 18. Sluisje van Oud 
samen $66 \mathrm{G}$ groot. In het $34 \mathrm{e}$ bg. zijn het de percelen: Blank 719-720; 723-729; 744-751; 775-776; 782-784; 794-797; 811 west; Uitk. 118/2; $118 / 3 ; 209$. In het centrum van Blankenberge zijn het de meeste percelen ten noorden van de Lange Straat. Hier dient bijgevoegd dat verschillende van die achterlenen een stuk in de zee verloren hebben.

\section{HET ONTSTAAN VAN DE BLANKENBERGSE WATERING}

Vóór de aanleg van de dijklijn Gentele-Evendijk-Zidelinge waterde het schorreland langs kreken rechtstreeks in de zee uit. Doch ook water uit de Zandstreek moest doorheen het genoemde gebied zijn weg naar de zee nemen. Het gaat hier om het afvloeiwater van een deel van Varsenare, Jabbeke en Ettelgem.

Zodra de dijk dicht was, verscheen het probleem van de afwatering, voor een gebied dat in feite ong. $200 \mathrm{~km}^{2}$ groot was. In de dijk moest een opening gelaten worden. Deze mocht niet onbeschermd blijven. Ongetwijfeld waren de sluizen in die periode primitief. Ook M. Gottschalk neemt „eenvoudige uitwateringssluizen" aan.

Een charter van St.-Bertijns levert ons een zeer vroege vermelding van een sluis: "Sarodsclusa super fluvio Sumno in pago Vermandense" in $708^{15}$. In de polders langs de IJzer, die na de Duinkerke III A gewonnen zijn, ontmoet R. Boterberge in 1163 een "sclusa”, de Venepesluis, die in 1184 als „magna sclusa" aangeduid wordt. De oudste vermelding van een andere sluis in dezelfde streek dateert uit 1187: „Bevericsluis” ${ }^{16}$.

Welnu, waar stond de eerste uitwateringssluis van het gewest, dat later de Blankenbergse Watering genoemd werd, en dat we gemakshalve nu reeds met deze laatste naam zullen anduiden? Tussen Brugge en Oudenburg bestond een waterloop, de latere Ieperleet, die op het oostelijke uiteinde uitmondde in de Reie, die vanuit Brugge in noordoostelijke richting langs een kreek naar de zee afvloeide.

Wat moesten de dijkbouwers doen op de plaats waar de Zidelinge en de Gentele de Leet zouden kruisen? Ze konden op beide kruispunten een sluisje bouwen. Het is echter zo dat de oudstbewaarde teksten op beide plaatsen geen sluis, doch wel een dwarsdam, nl. een overdrag vermelden: 1. te Oudenburg: ,of oest alf der overdraghe" (1286); ,ter overdraghe" (1310) ${ }^{17}$; 2. te Scheepstale bij Brugge: ,te sceipstale bi den overdraghe" (1401) ${ }^{18}$; het zuidelijke uiteinde van de Blankenbergse Dijk lag in 1630 "daer wijlent in den Yperleet het overdraght te staen placht" ${ }^{19}$.

De attestaties zijn evenwel niet oud genoeg om te bewijzen dat op de genoemde twee punten niet eerst een sluisje gestaan heeft. We hebben immers en sterk vermoeden dat er in de Gentele eerst een sluis gebouwd is. In 1288 ontstond een betwisting tussen de stad Brugge en de wateringen

(15) D. Haigneré, Chartes St.-Bertin, 1, p. 5 (1886).

(16) R. Boterberge, o.c., p. 115-116.

(17) M. Gysseling, o.c., p. 187.

(18) SAB, Rek. Stad Brugge, 1401-02, fo $47 \mathrm{v}^{\circ}$.

(19) Blank. Wat. nr 311, Verpachting Blank. Dijk (1630). 
Eiesluis en Reigaarsvliet aangaande het onderhoud van twee bruggen op de Leet. De ene brug ,heetende... sceepsbrucghe, gaende te Lisseweghe waerd”, lag ten noorden van het klooster van St.-Klara, „ende dandre boesten sente Claren, gaende te Dudzele waerd".

Eiesluis en Reigaersvliet houden staande dat Brugge verplicht is de twee bruggen te onderhouden. Hun argument blijkt niet alleen doorslaggevend voor het scheidsgerecht, maar is ook zeer belangrijk voor de studie van de waterwegen: „bi der redenen dat die van den ambachte tusschen der ghentele ende der sidelinghe hadden ghesyn in houtnessen ende van rechte die vorseide brucghen te makene ende te houdene, ende die van der poort vorseit hemlieden dat land ende dat water, daer die brucghen over gaen, of hadden ghewonnen, dat te haerre wateringhe behorde, duer welx lants wille zie die brucghen makeden ende staende hilden" ${ }^{20}$.

Uit de bovenstaande tekst halen we de volgende gegevens: 1 . De twee bruggen lagen over een stuk van de Leet buiten de Blankenbergse Watering, nl. tussen de Gentele en de Reie. 2. Het bedoelde deel van de Leet behoorde oorspronkelijk aan het ,ambacht tusschen der ghentele ende der zidelinghe" d.w.z. aan de Blankenbergse Watering. 3. Het waterschap had op beide oevers een dijkje gelegd om alle kontakt met het afvoerwater van het nevenliggend terrein te beletten. Inderdaad, de noordelijke dijk van de Leet was de zuidgrens van de wateringen Eiesluis en Reigaersvliet. 4. Het waterschap moest, als eigenaar, niet alleen de waterloop en de dijken, maar ook de verbindingen over de waterloop heen onderhouden. 5. De Blankenbergse Watering heeft enkele jaren vóór 1288 „dat land ende dat water” buiten de Gentele aan Brugge afgestaan. Sedertdien rustte de onderhoudsplicht op de stad.

Uit dit alles kan men afleiden dat de Blankenbergse Watering in de eerste eeuw van zijn bestaan ten noorden van Brugge langs de Leet afwaterde. Hoe kan men anders uitleggen waarom het waterschap eigenaar was van het stuk van de Leet, dat buiten de dijk liep? We kennen echter geen enkele tekst, die een sluis op de bedoelde uitwateringsweg aanwijst.

Langs welke weg ook het overtollige water afliep, toch rezen dadelijk na de bouw van de dijklijn de volgende vraagstukken: Wie zal de afvoerweg onderhouden? Wie zal het waterlopennet inrichten? Wie zal de zeewering staande houden? Wie zal verantwoordelijk zijn voor de zaken, die de gemeenschappelijke gelanden aangaan?

Zowel de eigenaars van het eerst ingepolderde land in Veurne-Ambacht, als die van de polder tussen Brugge en Oudenburg, konden niet steunen op de ervaring van oudere polders. Hoe dan ook, ze waren verplicht om samen te werken om het zeewater buiten hun gronden te houden en het overtollige verse water buiten te krijgen. Het kan niet anders of de gelanden hebben zich verenigd in een ,ambacht". Deze laatste term kon allerlei organizaties aanduiden: 1 . een vereniging van vaklieden, b.v. het ambacht van de smeden; 2. een administratief gebied, b.v. het Ambacht Dudzele; 3. een waterschap, een "waes ambacht".

(20) SAB, Rudenbouck, fo $16 \mathrm{v}^{\circ}$ (1288). 
Uiteraard weten we niet hoe een watering in het beginstadium ingericht was. Wanneer werd de funktie van ,waes schoutete” ingesteld? Bestonden de verplichtingen van de gelanden aanvankelijk uit werkprestaties? Daarmee bedoelen we dat aan iedere gelande, naargelang zijn grondbezit, zijn deel in de werken van het waterschap toegewezen werd.

Zulke toestand kon niet lang blijven duren. Het moet zeker in het begin van de 11 e eeuw nodig geworden zijn een geheel van vaste reglementen op te stellen. De gelanden dienden een geldelijke bijdrage op te brengen voor de gemeenschap. De bijdrage werd vastgesteld per gemet (lat. mensura), d.i. de oppervlakte grond, die in één dag door één ploeg kan omgewerkt worden (44 aren).

Reeds vroeg bestond tussen de Gentele en de Zidelinge een vereniging binnen een waasambacht. Immers de polders, die na de Duinkerke II A ten oosten van de Gentele en ten westen van de Zidelinge gewonnen werden, hebben vele van de statuten van de Blankenbergse Watering overgenomen. De wateringen van deze streken beschouwden de Blankenbergse als de oudste.

Ieder jaar werd een bijdrage per gemet ,geschoten”. Dit was het gewone watergeld of -geschot. Wanneer de zeewering grote kosten vroeg, werd een dijkgeld geschoten. De ontvanger hield rekening van de inkomsten en de uitgaven. De sluismeesters zorgden voor het onderhoud van de zeedijken. de sluis, de watergangen, de wegen en de bruggen. De waasschouteet waakte nauwgezet op het innen van ieders geschot. Doch het oppertoezicht op alle wateringen in het Bruge Vrije kwam uitsluitend aan de schepenen van het Vrije toe.

De oudste ons bekende vermelding van een jaarlijks watergeld stamt uit een rekening van het St.-Janshospitaal: „extradatum in nummis aquarum" (1280). De oudste benaming van de Blankenbergse Watering verschijnt in 1288 , ,in nummis aquarum inter ghentele et zilinghe”. De rekening van 1307 bevestigt én de term geschot én de naam van het waterschap: „,van iscote tusschen der ghentele ende der zilinghe" ${ }^{21}$.

$\mathrm{Na}$ deze lange uitweiding over de vroegste tijden van de wateringen, moeten we terugkeren naar de uitwateringsweg van de Blankenbergse Watering. Indien in de $11 \mathrm{e}$ eeuw werkelijk een opening, met of zonder sluis, in de Gentele bestaan heeft, dan zal deze met een dwarsdam dicht gemaakt zijn, zodra het land ten oosten van de Gentele ingedijkt werd en een afzonderlijk waterschap ging vormen (tweede helft 11e eeuw).

Inderdaad, in de $12 \mathrm{e}$ eeuw verliep de afwatering alleszins niet meer langs de Leet. De Grote Ede, later Blankenbergse Vaart genoemd, bezat toen reeds de uitwateringssluis. Dit leiden we af uit een charter van St.-Donaas uit de 2e helft van de elfde eeuw, dat de oprichting van een parochie Wenduine mededeelt. St.-Donaas scheidde toen een deel van het grondgebied van de parochie Uitkerke af. Als grens werd de ,slusflit" genomen ${ }^{22}$. Deze vliet vormt nog steeds dezelfde grens.

Ondertussen was het schorreland ten noorden van de Evendijk door een

(21) St.-Janshosp. Rek. rol nr. 5 (1280), nr. 12 (1288), nr. 30 (1307).

(22) Cart. St.-Donaas, fo $75 \mathrm{v}^{\circ}$ (ong. 1185). 
nieuwe dijk gewonnen. Deze dijk, samen met een strook grond erachter, is later weer door de zee ingenomen. Daardoor kan niemand zeggen waar de eerste zeesluis van de Blankenbergse Watering gestaan heeft. Toch menen we dat ze niet in de zeedijk zelf gebouwd werd, maar wel enkele meters achteruit om haar niet helemaal aan het geweld van de zee bloot te stellen.

De grond ten noorden van de Evendijk maakte, of maakt nog, deel uit van het waterschap tussen de Gentele en de Zidelinge. Het genoemde waterschap was groter dan de omliggende. Daarom noemden ze het gewoonlijk de Grote Watering. De wateringen ten oosten van de Gentele gebruikten de term West-Watering ${ }^{23}$.

De stad Blankenberge won vervolgens aan bekendheid. Dit feit veroorzaakte in de loop van de $14 \mathrm{e}$ eeuw een verschuiving in de naamgeving. De naam Sluis van Blankenberge kwam in voege, omdat de zeesluis op de westgrens van het gebied van de stad stond. De namen Sluisvliet, Gentele en Grote Watering werden vervangen door de termen Zwin van Blankenberge, Blankenbergse Dijk en Watering van Blankenberge. Toch noemden de klerk en de sluismeesters hun waterschap, op het einde van de $14 \mathrm{e}$ eeuw nog steeds ,tusschen der ghentele ende der zilinghe”.

\section{HET LAND TEN OOSTEN VAN DE GENTELE}

In paragraaf 3 hebben we uiteengezet waarom we de bouw van de Gentele vóór het jaar 1000 stellen. Het grootste deel van het land ten oosten van de Gentele kende in de eerste helft van de $11 \mathrm{e}$ eeuw de Duinkerke III A transgressie. De overstroming heeft echter de grond rond Lissewege en Dudzele niet overspoeld. Beide dorpskernen staan op Oudland. Ook langs de Gentele is de transgressie slechts tot ter hoogte van St.-Jan gevorderd.

Ovier de meeste terpen ten oosten van de Gentele kan men moeilijk zeggen of ze vóór de iuinkerke III A, dan wel pas daarna opgeworpen zijn. Alleen een bodemkundig en archeologisch onderzoek kan hun ouderdom bepalen. Toch veronderstellen we dat de ronde vluchtheuvels de oudste zijn.

De geschreven bronnen wijzen ons drie terpen aan ten noordwesten van St.-Jan. Een vierde wal is de grote woonterp, waarop de kom van Uitkerke ontstaan is. De genoemde vier terpen werden, met een strook schorreland, enkele jaren na de Duinkerke III A door een dijk veilig gesteld. Totnogtoe kennen we geen oudere vermelding van Uitkerke dan 1089.

De aangehaalde dijk heet Dulleweg. Hij vertrekt uit St.-Pieter-op-deDijk. Evenals bij de Gentele is het zuidelijke eind breder. Ten oosten van Zuienkerke bereikt de Dulleweg $24 \mathrm{~m}$, ten oosten van St.-Jan-op-de-Dijk $\pm 20 \mathrm{~m}$, ten zuidwesten van Uitkerke $17 \mathrm{~m}$. Verder noordelijk versmalt de dijk. Dit laatste stuk werd ook Zidelinge genoemd.

De terpen in het land ten oosten van de Dulleweg werden reeds in paragraaf 2 besproken. Een tweede Evendijk heeft een groot gedeelte van

(23) RAB, Charter Vrije nr. 162 (1337). 
het bedoelde gebied tegen de zee veilig gesteld. Deze lange dijklijn maakte het ontstaan en uitgroeien van nieuwe dorpen mogelijk. De vermeldingen van de parochies Lissewege, Dudzele en Oostkerke in de oorkonde van 1089, en van Westkapelle in $1110^{24}$, tonen aan dat de streek rond de genoemde dorpen reeds enkele jaren vóór 1100 tegen overstroming beschermd was.

De Evendijk is $18 \mathrm{~m}$ breed ten oosten van Uitkerke, ten noorden van Koudekerke $\pm 20 \mathrm{~m}$. In de sektor tussen uitkerke en Koudekerke kunnen we, dank zij de bodemkaart van J. Amerijckx ${ }^{25}$ acht dijkbreuken aanwijzen. Zes van de acht vingerlingen bestaan nog. Ten oosten van Koudekerke buigt de Evendijk naar het oosten af. Het afbuigende stuk heet Zomerdijk.

Van de grens van Westkapelle tot Reigaarsvliet kreeg de dijk de naam Kalveketedijk, omdat de bedoelde sektor aan het Hof van Kalvekete toebehoorde. Tussen Reigaarsvliet en Hoeke is de naam Oostdijk of Brolozedijk. Bij Hoeke buigt de dijk naar het zuidwesten en loopt hij tot ten zuiden van Damme. Dit lange stuk heette aanvankelijk Lange Dijk.

Wie de kaart van de watering Eiesluis-Reigaarsvliet van J. Drubbele (1838) aandachtig bestudeert, herkent verschillende kreekaders van de Duinkerke II en III A, waarlangs het schorreland afgewaterd heeft. De belangrijkste kreek was de waterloop, die door de schorren stroomde, van Brugge naar de zee. Binnen de stad heet deze beek thans de Reie. Van Brugge tot de zee droeg ze de naam Scheure. Ten zuiden en ten oosten van Oostkerke verenigden kleinere waterlopen, o.a. de Ede, de Vliet, de Monnikerede en de Grote Vliet zich met de Scheure ${ }^{26}$. Deze laatste diende na de Duinkerke II niet alleen als afvoerweg voor het water van boven Brugge, maar ook als vaarweg van de zee naar Brugge.

Naarmate het schorreland ten noorden van Brugge aangroeide, zullen de kreken tekenen van verlanding vertoond hebben. Toen trad de Duinkerke III $A$ in. De Scheure werd door de schuring van ebbe en vloed opnieuw breder. Ook M. Gottschalk wijst erop dat bij overstromingen oude kreken als getijdegeulen dienden. In de 11e eeuw werd de benedenloop van de Scheure met de naam Boudewijnsvliet aangeduid ${ }^{27}$.

Wat gebeurde er met de kreken bij de aanleg van de Evendijk? De bouwers hebben de dijk niet op de uiterste rand van het schorreland gezet. Langs de noordzijde en de oostzijde lieten ze een strand van ong. $1 \mathrm{~km}$ liggen. Ook aan de zuidoostzijde volgde hun dijk de brede Boudensvliet niet te dichtbij. De dijk overdamde de Scheure en de andere kleinere kreken op een plaats, waar deze niet meer zo breed waren.

De Monnikenrede werd opgehouden en voorzien van een sluis. De Scheure werd langs de binnenzijde van de Lange Dijk doorgetrokken tot aan de Monnikerede. De ingelanden hebben de afvloeiing van de overige aders naar de sluis gericht ${ }^{28}$. De Scheure bleef steeds de vaarweg van Brugge naar de zee. Het zuidelijke einde, tussen Brugge en Koolkerke, is na de bouw van het Fort van Beieren, in de $18 \mathrm{e}$ eeuw erg vervallen geraakt. Ten-

(24) Dr. A. Verhulst, o.c., p. 30 (1964).

(25) J. Ameryckx, Bodemkaart België, Kaartblad Heist 11 W (1954).

(26) R. De Keyser, R.d.P., 6e jg., nr. 4, p. 123 (1964).

(27) R. De Keyser, R.d.P., 2e jg. nr. 3, p. 7 (1960).

(28) R. De Keyser, R.d.P., 6e jg. nr. 4, p. 123 (1964). 
gevolge van dit feit is de genoemde waterloop ontsnapt aan de aandacht van velen, die zochten naar de weg waarlangs het water van Brugge afvloeide.

Ongetwijfeld hebben de gelanden binnen de Evendijk dadelijk een gemeenschap gesticht. Ze konden daarbij steunen op de ervaringen van het waasambacht tussen Gentele en Zidelinge. We bezitten geen enkele aanduiding aangaande de vroegste naam van het nieuwe waterschap. Wel weten we dat de Leet als zuidgrens genomen is. De Leet mondde in de Scheure uit, ongeveer $1 \mathrm{~km}$ ten noorden van de oudste omwalling van Brugge.

De afwatering van de gronden, die het verst van de sluis gelegen waren, nl. ten noorden van Lissewege en van Ramskapelle, zal niet steeds vlot verlopen zijn. De toestand verbeterde zeker niet gedurende de Duinkerke III B. Deze transgressie heeft de Boudensvliet verbreed en verdiept tot een zeearm. Ten oosten van Oostkerke werd een lang stuk van de Lange Dijk weggeslagen. De grote vingerling is in de Krinkeldijk nog duidelijk zichtbaar ${ }^{29}$.

Ten oosten van Westkapelle werd een getijdegeul, de Reigaarsvliet, uitgeschuurd. Waar de vloed de kreek tot tegen de Brolozedijk uitspoelde, heeft hij een stuk van de dijk vernield. De bochten in de dijk herinneren aan het geweld van de zee. Ten noorden van Lissewege reikte een vloedkreek, de Olevliet, tot aan de Evendijk. Hier ligt één van de bovengenoemde acht vingerlingen ${ }^{30}$.

De zeearm buiten de dijk, met in zijn monding de eilanden Kadzand en Wulpen, wordt in 1187 als „Swen” vermeld ${ }^{31}$. Terloops stippen we aan dat de termen Zwin, Scheure, Ede en Vliet oorspronkelijk benamingen waren voor een natuurlijke waterloop in de kustvlakte ten noorden van Brugge. Vele waterlopen heetten eenvoudig Ede of Zwin. Door het toevoegen van een bepaling ontstonden geleidelijk eigennamen. Doch voor de grootste stroom van de streek was de naam „t swin" voldoende.

Het is wel waar dat de Duinkerke III B gedeeltelijk achter de Lange Dijk om gevloeid is. Toch reikte het Zwin, dat zich buiten de dijk in de bedding van de Boudensvliet vormde, met geen enkele ader tot aan Brugge. De Scheure vormde de vaarweg. Algauw zocht Brugge zijn waterweg te verbeteren. Een kunstmatig zwin werd gegraven. Vanaf de stad tot even voorbij de monding van de Leet neemt dit zwin de bedding van de Reie en de Scheure in. Verder verlaat de nieuwe watergang de oude waterloop en loopt ten westen van de Scheure naar het noorden.

Op beide oevers werd een dijkje gelegd om het waterpeil te verhogen. De twee dijken en de watergang behoorden aan Brugge. Dit eigendomsrecht strekte slechts tot Pylysersdam te Oostkerke. De stad behoefde niet verder dan tot het genoemde punt te delven vermits daar de Monnikerede voorhanden was, die bij het kasteel van Lembeke met een sluis in het Zwin uitmondde. De Monnikerede werd van dijken voorzien. De dijken en de sluis bij Lembeke behoorden later aan het stadje Monnikerede. Er is inder-

(29) J. Ameryckx, Bodemkaart van België, Kaartblad 11 E, Westkapelle (1954).

(30) J. Drubbele, Kaart Watering Eiesluis-Reigaarsvliet (1838).

(31) Dr. A. Verhulst, o.c., p. 29. 
daad op de Monnikerede scheepvaart geweest, totdat de stad Monnikerede in 1266 verplicht werd haar sluis te vernauwen om het doorvaren van schepen te beletten ${ }^{32}$.

De nieuwe watergang, die enkele tientallen jaren later het Oud Zwin zal genoemd worden, is waarschijnlijk in het midden van de $12 \mathrm{e}$ eeuw aangelegd. Volgens Gualbertus vluchtte een van de moordenaars van Karel de Goede in 1127 per boot uit Brugge naar Michem. Deze nederzetting lag langs de Scheure, ong. $5 \mathrm{~km}$ ten noorden van Brugge. Dit feit bewijst wel niet dat de Scheure dan nog de enige vaarweg was, maar ook niet dat het zg. Oud Zwin toen reeds bestond.

De nieuwe watergang met zijn dijken heeft een paar aders van de afwatering doorgesneden en een eerste scheiding veroorzaakt in het afwateringssisteem binnen de Evendijk. De Scheure diende verder om het overtollig water tussen het Oud Zwin en de Lange Dijk af te voeren. Maar het land ten westen van de vaarweg van Brugge was afgesneden van de uitwateringssluis, die zich ong. $200 \mathrm{~m}$ ten zuiden van het stadje Monnikerede bij Lembeke bevond.

Het waterschap heeft een nieuw uitwateringspunt gevormd ten oosten van Westkapelle. In die buurt kronkelde een kreek, het Kromme Water, waarvan de afvloei naar de sluis bij Lembeke gericht was. Er werd een watergang gedolven van het Kromme Water recht naar de Reigaarsvliet. Deze watergang werd van dijkjes voorzien en de sluis kreeg zijn plaats, niet op het eindpunt in de Brolozedijk, maar op het beginpunt bij het Kromme water. Dat was de Kwintenssluis. Tegelijk heeft het waterschap een nieuw watergeleed getrokken doorheen het Ambacht Dudzele, nl. de Rondsaertader. Deze nam het water van alle aders, die hij doorkruiste, mede naar het Kromme Water ${ }^{33}$.

$\mathrm{Na}$ de Duinkerke III B-transgressie heeft Graaf Filips van de Elzas in 1180 de stad Damme gesticht. Brugge kreeg nu de kans om een rechtstreekse verbinding naar het Zwin te graven. De nieuwe vaart moet vóór 1200 tot stand gekomen zijn. Hij takt af van de Reie buiten de oude stadsomwalling.

Ook de Nieuwe Reie had dijken. Te Damme werd een sluis gebouwd om het hogere waterpeil te behouden en om het zeewater van het Zwin buiten het kanaal te houden. Er begon zich stilaan een net van bevaarbare waterlopen met hoger peil te vormen, waarbij ook de Leet aangesloten was. Na het graven van het nieuwe „swin”, verviel de oude waterweg van Brugge langs de Monnikerede naar de zee en kreeg gemakkelijk de naam Oud Zwin. Het Oud Zwin was niet meer aangesloten bij het hogere peil. Aan het knooppunt met de Leet werd een sluisje gebouwd om te beletten dat te veel water naar het Oud Zwin afvloeide.

Want, hoewel het Oud Zwin nog plaatselijke scheepvaart kende, toch was hij voor Brugge de aangewezen weg geworden om overtollig water af te voeren. Brugge heeft de afvoer van winterwater nog kunnen verbeteren, wanneer het waterschap, dat toen reeds te Reigaarsvliet uitloosde, het Oud

(32) Dr. J. De Smet, Monnikerede, p. 4.

(33) R. De Keyser, art. cit., p. 126. 
Zwin langs Eienbroek met de Kwintinssluis verbonden heeft. Er kwam zelfs een akkoord tot stand tussen Brugge en de watering Reigaarsvliet: enerzijds mocht de stad alle overtollig water afvoeren naar de sluis van Reigaarsvliet , anderzijds moest ze voor een deel tussenkomen in het onderhoud van de sluis van de watering ${ }^{34}$.

Omstreeks 1200 werd het net van vaarwegen ten noorden van Brugge uitgebreid. De Evoorde werd gegraven. Deze strekte vanuit de Rondsaertader recht naar het noorden tot ten noordwesten van Dudzele. Op dit punt sloot hij aan bij de Noord- en de Zuid-Watergang. Dank zij de Evoorde beschikte de streek van Dudzele, Ramskapelle en Westkapelle over een verbinding te water. We wijzen er echter op dat de Evoorde en de andere twee watergangen slechts het peil van de gewone wateringsaders hadden, en dus in de zomer weinig of niet bevaarbaar waren.

Ongeveer tegelijk met de Evoorde werd een watergang naar Lissewege gedolven. We zullen in de volgende paragraaf langer uitweiden over de Lisseweegse Watergang, omdat zijn naam al heel wat verwarring veroorzaakt heeft bij het zoeken naar het beginpunt van de bewuste waterloop.

\section{DE LISSEWEEGSE WATERGANG}

Vooreerst herhalen we even dat de Ieperleet in de 11e eeuw langs de Scheure met de zee verbonden was, en omwille van de afwatering reeds vroeg dijkjes gekregen heeft. In de $12 \mathrm{e}$ eeuw groef Brugge, naast de Scheure, een kunstmatige vaarweg, voorzien van dijken, nl. het Oud Zwin. Op die manier kwam, van de Gentele tot Lembeke, een verhoogd waterpeil tot stand. Op het einde van de twaalfde eeuw werd het Oud Zwin als vaarweg vervangen door de Reie, die tot Damme doorgetrokken werd.

Het oud Zwin verviel als waterweg. Zodra de nieuwe Reie de hoofdvaarweg werd, moest een sluisje gebouwd worden op het beginpunt van het Oud Zwin. Zoniet verloor de stad Brugge het water, dat ze nodig had om in de Reie te varen. Verder kon geen enkele waterloop rechtstreeks bij de Reie of bij de Leet aangesloten worden, tenzij op beide oevers dijken, en op het uiteinde een sluis gebouwd werden.

Ondertussen werd de strook schorreland ten noorden van de Evendijk ingedijkt. Het water van de nieuwe polder, de Oudemaarspolder, werd doorheen de Evendijk naar de Kwintenssluis gericht. De hoofdwatergang van de polder liep langs de Koppesluis naar de Kemelader en verder naar het Kromme Water. Niet alleen schreed de inpoldering verder, ook het net van waterlopen met laag peil werd uitgebreid. Omstreeks 1200 dolf men de Evoorde en de Lissewegerede.

De Lisseweegse Watergang takt af van de Leet ten noorden van het St.-Klaraklooster. Op het knooppunt werd de speie gebouwd, die later de Monnikenspeie genoemd werd. Maar om te bewijzen dat de genoemde sluis nooit op een andere plaats gestaan heeft, is het nodig eerst een aantal verkeerde tekstinterpretaties recht te zetten, ook indien ze, kronologisch gezien, op de geschiedenis van het Lisseweegse Vaartje vooruitlopen.

(34) idem, p. 138. 
Zoals blijkt uit paragraaf 4, heeft de stad Brugge het stuk van de Leet, tussen de Gentele en de Reie, van de Blankenbergse Watering overgenomen. De waterlopen binnen Brugge, zowel gegravene als natuurlijke, werden gewoonlijk met de naam Reie aangeduid. De term Reie is al vroeg overgegaan ook op het deel van de Leet, dat Brugge verworven had. Zodra we dit laatste ingezien hadden, was het niet moeilijk de volgende tekst uit 1282 te interpreteren: (een perceel), ,ligghende bachten Frerinnen, noerdover de Reye, bider moneke spoie van der Does ande westzide, beghinnende an den diic van de Reye ende streckende noerdward tote Raven Danwils ende Hannekins Lamsins Hamers soens lande, ande westzide van denwelken lande vorseit leghet s Pieters Bugghers land, an dostzide der meentucht zidelinghe die utwatert te Heyensluus" 35.

De schrijver situeert het perceel, gezien vanuit de stad Brugge. „Bachten Frerinnen" betekent achter het St.-Klaraklooster, d.w.z. ten noorden ervan; „noerdover de Reye" is ten noorden van de, als Reie aangeduide, Leet; "der meentucht zidelinghe die utwatert te Heyensluus" is de in 1279 aangelegde dijk op de westoever van de Lissewege Watergang, die aan de Watering Eiesluis toebehoorde. Kortom, het bedoelde perceel lag even ten westen van de Monnikenspeie en had als grenzen: west, een perceel van Pieter Buggher; noord, grond van Raven Danwil en van Hanneken Hamer; oost, de westdijk van het Lisseweegse Vaartje; zuid, de Leet, alias de Reie.

En wanneer oorkonden van 1246 en van 1276 verklaren dat de Abdij ter Doest bezit „spoyam inter Roiam et Lissewegher Hei" dan begrijpen we dadelijk dat de gemelde speie de schakel is tussen de Lissewegerede en de Leet.

Laten we nu de loop van het Lisseweegse Vaartje volgen. Over zijn gehele lengte heeft de nieuwe watergang tenminste vier van de bestaande wateringaders doorkruist; 1 . de Bommelbeek, ong. $1 \mathrm{~km}$ ten noorden van de Leet; 2. de Ede, ong. $3 \mathrm{~km}$ ten noorden van de Leet; 3. de Grote Vliet, $2 \mathrm{~km}$ ten zuiden van Lissewege; 4 . de Kemelader, te Lissewege.

De Lissewegerede ligt ongeveer 100 meter ten westen van de dorpskom van Lissewege en eindigt bij de Zandscheerweg, $2 \mathrm{~km}$ ten noorden van Lissewege. Het noordelijke eindpunt werd afgesloten met een dwarsdam, die omstreeks 1300 nog heette de dam ,benoerden Boudekins Blonden”. Ten noorden van deze dam is er vóór de 16e eeuw geen verdere vaarweg gegraven. De definitieve naam van de dam verschijnt in 1357: „Zwankendamme" ${ }^{36}$.

Het waterpeil van de Lissewegerede was lager dan dat van de Leet, vermits de nieuwe vaarweg niet van dijken voorzien werd. Het feit dat op het noordeinde een dam gelegd werd, verplicht ons aan te nemen dat het peil van de Lisseweegse Watergang hoger gehouden werd dan dat van de doorkruiste aders. Dit was misschien wel niet zo vanaf het eerste jaar, maar het zal zo geworden zijn, zodra de Abdij Ter Doest het recht kreeg om de watergang te gebruiken en de sluis op de Leet in handen had.

Uit de oorkonde van 1219 blijkt dat Ter Doest in het genoemde jaar

(35) Van de Putte, Cartularium ter Duinen, p. 629 (1864).

(36) RAB, Charter Vrije, nr. 231 (1357). 
reeds een eigen verbindingsweg van de abdij naar de „Liswegherhe” bezat, de zg. Doestarm ${ }^{37}$. De Lisseweegse Watergang zelf heeft nooit aan Ter Doest behoord. Omwille van deze vaststelling neemt S. Astaes aan dat de Lissewegerede vóór het ontstaan van de abdij gegraven is. In dit geval moet men de aanleg van het Lisseweegse Vaartje omstreeks 1200 stellen. We menen dat Brugge, zodra Ter Doest de Monnikenspeie kontroleerde, een sluisje gebouwd heeft op het knooppunt Oud Zwin-Leet, om te beletten dat te veel vaarwater naar de Lisseweegse Watergang afvloeide. Zoals het graven van het Oud Zwin noodzaakte tot het graven van een nieuwe afwateringsweg en het bouwen van een nieuwe sluis, nl. de Kwintenssluis, zo ook heeft de aanleg van de Lisseweegse Watergang een nieuwe afwateringsweg en een nieuwe uitwateringssluis doen ontstaan.

Het waterschap binnen de Evendijk was verplicht de afgesneden aders tussen de Gentele en de Lissewegerede met elkaar te verbinden en naar het noorden te richten. De nieuw gevormde wateringsader heet de Lange Watergang. Men bracht hem in verbinding met de Ede in de Oudemaarspolder. Er werd een zeesluis gebouwd in de Ede: de Eiesluis.

Er bestaat geen enkel bewijs dat het waterschap dadelijk na de bouw van de tweede uitwateringssluis in twee delen gesplitst werd, nl. een gebied dat uitwaterde te Reigaarsvliet, en een gebied dat uitwaterde te Eiesluis. Maar ook het feit, dat we pas in 1279 met de twee wateringen Reigaarsvliet en Eiesluis kennis maken, bewijst niet dat de splitsing slechts weinige jaren vóór 1279 gebeurd is.

We vernemen de splitsing tengevolge van een betwisting in wateringzaken. Omwille van hun scheepvaart in de Lissewegerede lieten de monniken van Ter Doest veel water uit de Leet afvloeien. Aangezien er geen dijken lagen, hadden de nevenliggende velden wel eens last ,,van den watre dat in coemet ter Moenekespeye". De gronden op de westoever behoorden aan de gelanden van de watering Eiesluis, de velden op de oostoever aan de gelanden van de watering Reigaersvliet.

Blijkbaar konden de twee wateringen niet beletten dat Ter Doest te veel water inliet. De betwisting werd een rechtszaak. Twaalf schepenen van het Vrije hebben oordeel geveld. Het vonnis bepaalde dat dijken moesten gelegd worden op beide oevers van de Lisseweegse Watergang om de aanpalende grond te beveiligen tegen het water, dat langs de Monnikenspeie ingelaten werd.

Het werk omvatte vijf sektoren: 1 . De dijk op de westoever, van de Monnikenspeie tot de Gizelebrug moest één roede breed zijn $(3,85 \mathrm{~m})$. Deze sektor en alle andere sektoren moest even hoog zijn als het terrein van de hofstede Gizele. Vermoedelijk staat deze oude nederzetting op een vroegere terp; 2. De westdijk, vanaf Gizele tot Zwankendamme, een halve roede breed; 3. De oostdijk, van Zwankendamme tot de Esinebrug, 1/2 roede. Het laatstgenoemde punt vormt tevens de grens tussen de ambachten Lissewege en Dudzele, en tussen de wateringen Eiesluis en Reigaarsvliet; 4. De oostdijk, van de Esinebrug tot de Monnikenspeie 1 roede; 5. De dam op het

(37) ASB, Charter nr. 287 (1219). 
noordeinde moest even hoog zijn als de zidelingen, en bovenaan twee roeden breed.

Het werk van de dijken werd opgelegd aan hen, die de watergang als vaarweg gebruikten, nl. de abdij zelf, en ook de watering Eiesluis, die ieder jaar langs de Lissewegerede materiaal aanvoerde voor het onderhoud van haar sluis en haar bruggen. Voor zover de zidelinge over het grondgebied van Eiesluis strekte, werd het maken ervan toegewezen aan deze watering; dit was van de Monnikenspeie tot Zwankendamme, en van Zwankendamme tot de Esinebrug.

Hoewel de dijk vanaf de Esinebrug tot de Monnikenspeie helemaal in Reigaarsvliet lag, toch moest Ter Doest het werk in deze sektor opknappen. Daarvoor kunnen de volgende twee argumenten gegolden hebben: 1. De gelanden van de watering Reigaarsvliet maakten nog geen gebruik van de watergang; 2 . In de genoemde sektor was ook de zidelinge vervat, die moest gelegd worden langs de arm van de watergang, die naar de abdij en rond de abdij liep. Dit stuk waterloop lag toch helemaal binnen het grondgebied van Ter Doest zelf.

Als laatste beslisten de schepenen dat het onderhoud van de sluis, die „der moeneke spoye" heette, op de eigenaar bleef rusten. Deze plicht gold ook nog in 1357, wanneer opnieuw een ruzie ontstaat tussen Ter Doest en de twee wateringen over het onderhoud van de Lisseweegse Watergang. De Vierschare van het Vrije vonniste dat alle delvingswerk aan de watergang bij de wateringen lag, en dat de Abdij de Monnikenspeie moest in stand houden ${ }^{38}$.

P. Gilliodts heeft door het verkeerd interpreteren van een tekst in de Brugse stadsrekening 1297-98 een ernstig misverstand veroorzaakt. Hij beweert immers dat Brugge in 1297 een nieuwe Monnikenspeie gebouwd heeft. Het gaat om de volgende tekst: „Balduino de Houtave et carpentariis pro ianuis faciendis in aquaductu de Lisseweghe... pro tegulis ad opus spoyke... pro calce ad dictum opus", enz. ${ }^{39}$.

Voordat we deze tekst bespreken, moeten we handelen over de nieuwe gordel, die in 1297 rond Brugge aangelegd werd. De stad heeft in 1297 en in 1298 bijzonder hard gewerkt om de nieuwe vestingsgracht te graven en de nieuwe wallen op te werpen. Er werden poorten gebouwd op de toegangswegen en houten torens op de wallen. In de noordoosthoek sloot de nieuwe gracht aan bij de Leet; even verder doorkruiste hij het Oud Zwin en de Reie.

Brugge kontroleerde reeds de watertoevoer aan de zuidrand van de stad door middel van de sluizen op de Boterbeek en het Minnewater. Het opwerpen van de nieuwe wallen verschafte een goede gelegenheid om het waterpeil binnen de stad beter te beheersen, nl. door een sluis te bouwen op het kruispunt walgracht-Reie. Dit is een reden waarom we menen dat het genoemde ,spoyke" eigenlijk de Speie bij de Speipoort is.

Laten we even nagaan hoeveel het bouwen van het ,spoyke" gekost heeft. We geven de posten in ponden parisis en in afgeronde cijfers: 530 pd

(38) Idem.

(39) Rek. Stad Brugge, 1297-98, $\mathrm{f}^{\circ} 14 \mathrm{r}^{\circ}$. 
voor bakstenen (tegulae); 215 pd voor kalk; 183 pd om zerkstenen (serpofagia) naar het werk te voeren; 595 pd voor de aankoop en het vervoer van Doornijkse steen; $370 \mathrm{pd}$ voor hout, dat diende voor de speie zelf en voor de oeverversterking van de Reie tussen de Speibrug en de oude stadswal: ,stadtbome a ponte spoyke versus villam”; 2232 pd voor het arbeidsloon. Er werden tevens twee houten torens gebouwd op de dijk naast de speie; een andere post toont het bestaan van een poort bij de speie. Het kan niet anders of het gaat hier om de Speie bij de Speibrug en bij de Speipoort, op de plaats waar de Reie de nieuwe stadswal passeert.

P. Gilliodts dacht dat de post „pro ianuis faciendis in aquaductu de Lisseweghe" verband hield met de posten, die de uitgaven ,ad opus spoyke” opsommen. Om die reden heeft hij de bedoelde speie op het beginpunt van de Lisseweegse Watergang gesitueerd. De bedoelde sluisdeuren (ianuae) werden wel in de vaarweg naar Lissewege geplaatst, maar in het sluisje dat de watertoevoer naar de Leet kontroleerde. Later werd boven dit sluisje de Lenaartpoort gebouwd. De rekening van 1414-15 zegt dat dit speike diende om te varen vanuit Brugge naar de Lisseweegse Watergang en naar de Ieperleet: „ligghende ten speykine $t$ sint Ledenaers poorte, dat dient ten waterganghe van der Does ende van der Ypperleet" ${ }^{40}$.

De oorsprong van alle misverstand betreffende de waterwegen in het noorden van Brugge ligt in het verkeerd verstaan van de tekst: ,,pro veteri roya ibidem implenda". Niet alleen voor Dr. A. Koch, maar ook voor ons betekent de term ,ibidem": bij de toren van Raven Danwilt, die bij de Speipoort gesitueerd wordt. Deze zg. Oude Reie lag dus in de buurt van de Speipoort. Het opvullen van dit stukje waterloop kostte in het geheel $3 \mathrm{pd}$ $18 \mathrm{~s} 8 \mathrm{~d}$ par! Naar onze mening gaat het hier om niets anders dan om het dempen van een verlaten bocht van de Reie.

\section{BRUGGE BEHEERSTE DE WATERTOEVOER UIT DE ZANDSTREEK}

Brugge is ontstaan bij de waterloop, die reeds in de 12e eeuw Reie heette. Het is moeilijk uit te maken wanneer in of bij Brugge het eerste sluisje gebouwd werd, dat de watertoevoer in de Reie regelde. Waarschijnlijk vormde de watermolen, die in de 12 e eeuw vermeld wordt, de eerste kunstmatige hindernis in een waterloop binnen Brugge.

Wat we wel weten is dat Brugge in de $12 \mathrm{e}$ eeuw een vaarweg, het latere Oud Zwin, gegraven heeft, dat aangesloten was bij de Leet en de gekanalizeerde Monnikenrede. Deze laatste mondde met een sluis in de Boudensvliet uit. Het water van de genoemde drie watergangen werd op peil gehouden door dijken. Daarnaast werd de Ronsaertader ingericht als afvoerweg voor het overtollige water van de stad Brugge en van de streek ten westen van het Oud Zwin. We zijn verplicht aan te nemen dat, wegens het verschil in waterpeil, een speike moest gebouwd worden op het punt, waar het overtollige water uit het Oud Zwin in de Ronsaertader afvloeide.

Waren het Oud Zwin en de Ronsaertader in staat om, ook in winters met buitenmatige regenval, de stad van wateroverlast vrij te houden? We

(40) Rek. Stad Brugge, 1414-15, fo $52 \mathrm{v}^{\circ}$. 
menen dat in zulke gevallen beide waterwegen niet voldeden, en dat het water wel eens over de oevers van de Reie binnen Brugge stroomde. Het beste middel om dit laatste te beletten was een sluis inrichten, waar de Reie de stad binnenkwam.

Zo kreeg Brugge stilaan kontrole over het water, dat uit de Zandstreek doorheen de stad zijn weg naar de zee zocht. In de zomer konden de Reie en het Oud Zwin het voorhandene water gemakkelijk bevatten. In de winter werd het overtollige water naar de Kwintenssluis geleid. Maar te overvloedig regenwater uit de Zandstreek werd bij de ingang van de stad tegengehouden.

Op het einde van de $12 \mathrm{e}$ eeuw werd de vaarweg verlegd naar de nieuwe Reie. Ook deze werd van dijken en van een sluis voorzien. Voortaan was het Oud Zwin de hoofdweg voor het overtollige water van Brugge. Doch zodra het Oud Zwin uit het net der waterloop met hoger peil geschakeld werd, moest een speike gebouwd bij het knooppunt Leet-Oud Zwin.

De oudste vermelding van de sluis te Damme is 1234, van de Monnikenspeie 1246, van het sluisje te Lembeke 1266. De rekeningen van de stad Brugge vermelden het sluisje op het beginpunt van het Oud Zwin voor het eerst uitdrukkelijk in 1287-88: „spoikin versus Colkerke" ${ }^{41}$. De term „parva spoike" in de rekening 1283-84 bedoelt waarschijnlijk hetzelfde sluisje; het wordt genoemd naast de sluis van Damme: „pro spoike et dico de Dam et parva spoike" ${ }^{42}$.

De Speie te Damme eiste gedurig toezicht en herstelling. Brugge besloot te Damme naast de Speie een huis te bouwen, waarin de sluiswachter zou wonen. In maart 1292 hebben een groot aantal stadsmagistraten een perceel geschat naast de Speie: „de estimando terram iuxta spoikin" ${ }^{43}$. Een tekst van mei 1292 vermeldt de aankoop van het perceel en situeert het tevens te Damme: „pro terra comparata infra portum de Dam domino Eustacio". De prijs was 100 pd pa. ${ }^{44}$.

We weten niet in welk jaar de stad haar sashuis te Damme gebouwd heeft. Het is echter een feit dat de ,speyhoudre”, Boudin van Houtave, in 1306 te Damme in een huis van de stad woonde. De stad liet immers het dak herstellen ${ }^{45}$. Brugge achtte één huis niet voldoende voor zijn personeel, dat te Damme de Speie gaande hield. In 1309 betaalde de ontvanger 220 pd par „Maertine Bradericke van enen huus, tieghen hem ghecocht ten Damme, staende daer an der stede huus" ${ }^{46}$.

Hetzelfde "der steden huus" wordt verder meermaals genoemd, o.a. in de tekst ,van den zeedike, die leghet bachten der steden huus ten Damme... te houden staende" ${ }^{47}$. Het bedoelde huis was niet het stadhuis van Damme, doch een huis dat aan de stad Brugge toebehoorde. Immers, wanneer de ontvanger van Brugge schreef: „der steden polre”, „der steden waterghanc”,

(41) Rek. Stad Brugge, 1287-88, fo $25 \mathrm{r}^{\circ}$.

(42) Rek. Stad Brugge, 1283-84, f $12 \mathrm{v}^{\circ}$.

(43) Rek. Stad Brugge, 1290-92, fo $29 \mathrm{v}^{\circ}$.

(44) Rek. Stad Brugge, 1292, fo $29 \mathrm{v}^{\circ}$.

(45) Rek. Stad Brugge, 1306, f $10 \mathrm{v}^{\circ}$.

(46) Rek. Stad Brugge, 1308-09, fo $25 \mathrm{r}^{\circ}$.

(47) Rek. Stad Brugge, 1350-51, f ${ }^{\circ} 59 \mathrm{v}^{\circ}$. 
„der steden teghelrie”, dan bedoelde hij telkens een eigendom van zijn eigen stad.

In paragraaf zes schreven we reeds dat Brugge een sluisje moet ingesteld hebben, om te beletten dat te veel water naar de Leet en de Lisseweegse Watergang afvloeide. Door in 1298 de Speipoort te bouwen had de stad de kontrole op het waterpeil nog vaster in handen.

$\mathrm{Nu}$ hebben we het over de wateraanvoer van boven Brugge. Twee beken stroomden de stad binnen vanuit het zuidoosten, de Boterbeek en de Brugse Leie. Beide werden gekontroleerd door een sluis, even ten zuiden van het Begijnhof. De rekeningen van Brugge van 1281-82, 1283-84 en 1287-88 noemen een „Huvaerds spoikin" 48 . Dit speike werd bewaakt door Rikaert van de Ee, die voor zijn werk een jaarloon kreeg. Vermoedelijk was Huvaertsspeike een naam voor de sluis op het Minnewater, die in 1292 „spoyke ad Lacum" heette ${ }^{49}$.

De stad had de Leie en de Boterbeek van een sluis voorzien, omdat ze reeds vroeg begrepen dat het water uit de Zandstreek voor tenminste drie doeleinden kon dienen: 1 . In de zomer de Reie met vaarwater spijzen; 2. In de winter de vaarweg doorspoelen; 3. De stad zelf met fris drinkwater bevoorraden.

Voordat we in de volgende paragraaf door een groot aantal teksten aantonen hoezeer Brugge naar het water van boven trachtte, geven we een algemeen overzicht van het stroomgebied ten zuiden van Brugge. Het ligt evenwel niet in onze bedoeling alle beken op te sommen, die in het behandelde gebied vloeien. Het stroomgebied van de Boterbeek is niet groot. Het beslaat slechts een deel van St.-Andries en van Varsenare. De belangrijkste bijrivier is de Abdijbeek, die begint in de buurt van de abdij van de Kartuizerinnen te Varsenare.

De Leie heeft veel bijrivieren. We bespreken eerst de westoever. Even buiten het Minnewater komt al de Kerkebeek aan. Deze brengt water aan vanuit St.-Michiels, Loppem, Zedelgem, Aartrijke en Veldegem. Ong. 2 $\mathrm{km}$ ten zuiden van de Kerkebeek mondt de Leiselebeek uit, die ten zuiden van Loppem ontspringt.

Te Moerbrugge vloeit een belangrijke bijrivier, de Rivierbeek, in de Leie. De Riviere ontspringt ten zuiden van Wingene en brengt water aan vanuit Wingene, Egem, Zwevezele, Hertsberge en Oostkamp. De Waardammebeek, die in de Rivierbeek uitmondt, ontwatert Waardamme, Ruddervoorde en een deel van Torhout, Lichtervelde en Zwevezele. Verder stroomopwaarts ontvangt de Leie het water van Beernem, St.-Joris-ten-Disdel en Aalter. Op de linkeroever van de Leie ontmoeten we op ong. $1 \mathrm{~km}$ ten zuiden van het Minnewater de monding van de St.-Trudoleet, die uit Assebroek komt. Verder bevinden zich kleine beken, die het water van Oedelem, en Knesselare aanvoeren.

Brugge heeft de bedding van de Leie en van haar voornaamste bijrivieren veel verbeterd en gedeeltelijk gekanalizeerd. Zulke beken worden in

(48) Rek. Stad Brugge, 1281-82, rol ; 1283-84, $\mathrm{f}^{\circ} 13 \mathrm{r}^{\circ}$. $1287-88, \mathrm{f}^{\circ} 19 \mathrm{r}^{\circ}$.

(49) Rek. Stad Brugge, 1292, $\mathrm{f}^{\circ} 19 \mathrm{v}^{\circ}$. 
de teksten dikwijls eenvoudig met de term watergang aangeduid. De Leie, die in het Minnewater aankwam, heette oof Brugse of Zuid-Leie, gesteld tegenover de Gentse Leie, die even ten noorden van Damme in het Zwin uitmondde. Brugge onderhield ook de bruggen over de waterlopen, die het onder zijn beheer had. We noemen hier slechts de bruggen over de Leie, vanBrugge tot Aalter: de Steenbrug, de Moerbrug, Gevaertsbrug, Bloemengembrug, de brug te St.-Joris, de Waalbrug en de Lendebrug.

\section{DE BEMOEIINGEN VAN BRUGGE IN HET STROOMGEBIED VAN DE ZUID-LEIE}

Uit de oudstbewaarde vermelding, die op de watertoevoer van boven zinspeelt, blijkt duidelijk dat Brugge reeds in de tweede helft van de $13 \mathrm{e}$ eeuw de kontrole op de Leie verworven heeft. De tekst van 1290-92 zegt: "pro inspectione fossati brugensis prope oestmuelne iuxta wastinam" 50, dit betekent: schouwing van de watergang van Brugge, bij de Oostmolen langs de Woestine. Dit laatste is ongetwijfeld de heerlijkheid van de Woestine te Aalter. Uit de aangehaalde tekst volgt dan dat de Leie reeds in 1290 een „fossatum brugense” was vanaf Brugge tot Aalter.

De vele onderstaande aanhalingen zullen aantonen welke bijrivieren door de stad gekontroleerd werden, en welke inspanningen Brugge zich getroostte om ze te onderhouden en te verbeteren. De Kerkebeek verschijnt in 1298-99: "pro fossato fodiendo a retro Beghinis usque ad Sancti Michaelis" 51. De genoemde waterloop vloeit inderdaad achter het Begijnhof en komt uit St.-Michiels.

Een uitgebreide tekst van 1306 toont dat Brugge reeds zekere rechten op het water van het stroomgebied van de Leie bezat, en hoe ver de belangstelling van Brugge reikte, nl. tot Hansbeke, d.i. tot ong. $25 \mathrm{~km}$ ten zuidoosten van de stad: „,varende te Orscamp, Bernem, Cnesselare, Haeltere, Ursele, Bellem ende te Hansebeike omme de Leye te beridene end orconde daerof te hoorne hoe varre datter de stede van Brucghe recht an heift" 52 .

$\mathrm{Na}$ deze schouwing werden enkele maatregelen genomen die niet voldeden: er kwam niet genoeg water aan langs de Leie tot in de stad. In 1312 werd een specialist ontboden om raad te schaffen: „meester Yustaes van der Does ende sinen cnape omme dat hi hier omboden was, omme te versiene de fauten van onsen watre, beede buten ende binnen" ${ }^{53}$. De beste raad, die meester Eustaas kon geven, was wel de bedding van de waterlopen verbeteren. In 1313 werd gedolven in een waterloop: „den delvers die den waterganc verdiepten omme te meer waters te hebbene binder stede" 54 .

Niet alleen werden de Leie en de beken op gezette tijden herdolven, Brugge, zorgde er ook voor dat de wateraanvoer uit kleine beken en uit zijgrachten niet belemmerd werd. Hun monding werd voorzien van een ge-

(50) Rek. Stad Brugge, 1290-92, fo 25 bis v $^{\circ}$.

(51) Rek. Stad Brugge, 1298-99, fo $23 \mathrm{r}^{\circ}$.

(52) Rek. Stad Brugge, 1306, fo $11 \mathrm{r}^{\circ}$.

(53) Rek. Stad Brugge, 1311-12, fo $32 \mathrm{r}^{\circ}$.

(54) Rek. Stad Brugge, 1312-13, fo $72 \mathrm{r}^{\circ}$. 


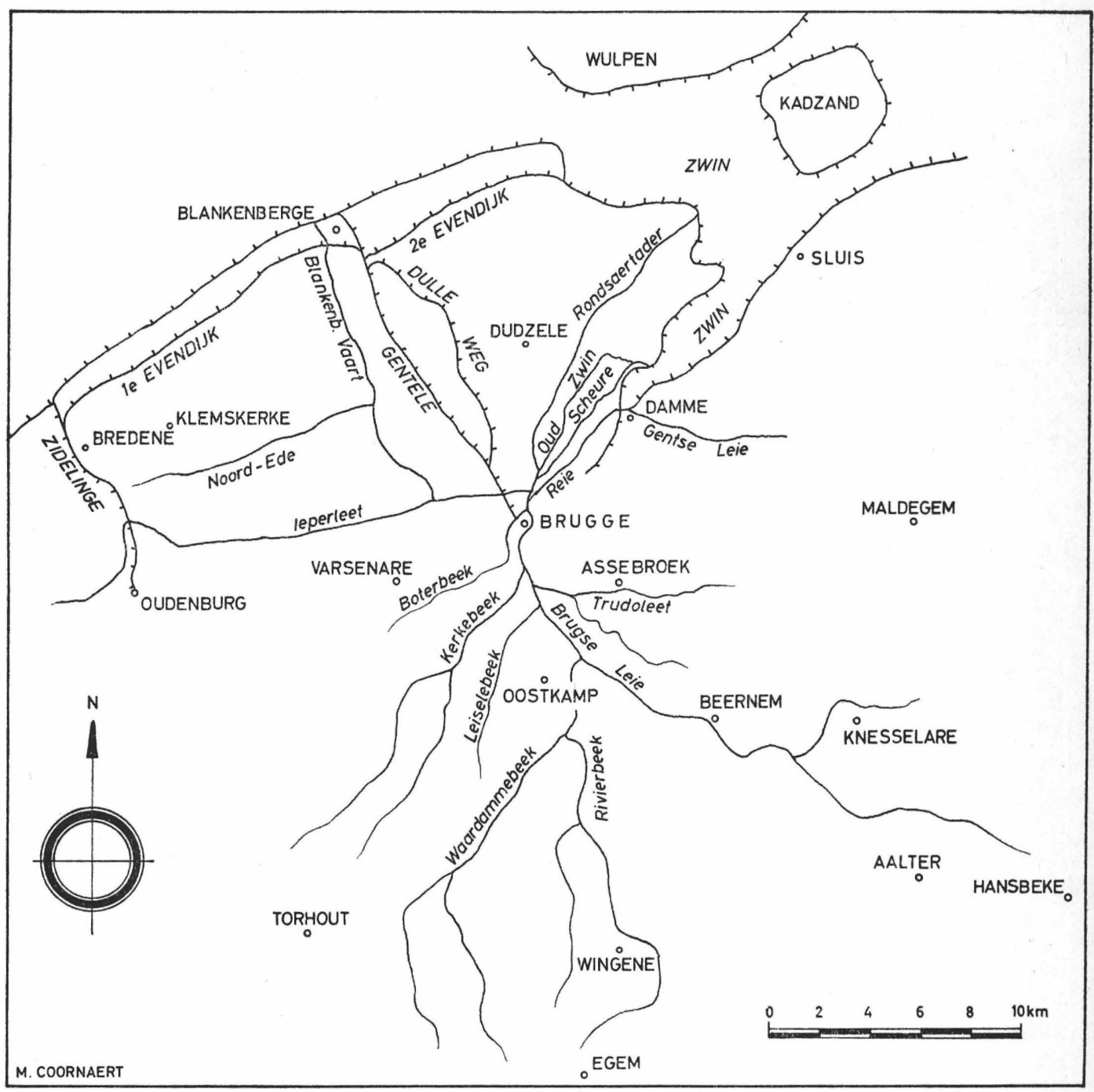


metste riool. In 1316 gebruikten metsers 4000 bakstenen om ,drie rioten te verwelvene, die vallen in den nieuwen waterganc" 55 .

In 1318 ontmoeten we de Stadsvijver. Deze lag bij St.-Baafs even buiten de Boeveriepoort. Daar vergaderde Brugge een voorraad drinkwater. De vijver werd gevoed door de Boterbeek, de Abdijbeek en kleinere beken. Deze waterlopen werden in 1318 gereinigd: ,van den beken te doen rumene boven den vivere bi sinte Baafs, omme $t$ water te bet in de port te commene" 56 . De voornaamste waterloop, die water naar de Stadsvijver bracht, werd in 1361 herdolven: „den waterganc, commende van boven ten vyvere waerd, ghedaen rumen ende ghedaen delven" ${ }^{57}$.

Ondertussen voldeed de Leie zelf hoegenaamd niet meer als aanvoerweg. In 1362 begon Brugge de waterloop helemaal te herdelven. Dat was ",twerc van der niewer Leye". In 1363 bereikten de delvers het grondgebied van Oedelem. Langs het nieuw gedolven eind werden stenen rioolmonden gebouwd. Als het moest, onteigende Brugge een perceel, „, dat der stede orbaerlic was te ere ryole ten orbare van den ghedelve van der vorseider Leye" 58 .

In 1367 was het werk van de vernieuwe Leie voorbij Knesselare gevorderd. Tegelijk werd een bijrivier herdolven: „van enen waterganghe te doen delvene bi Knesselare, commende in de nieuwe Leye, omme t proffyt van de stede" 59 . De Brugse Leie naderde meer en meer het Gentse waterbekken. Gent begon te vrezen dat Brugge te veel water naar zijn kant zou trekken. Het ingrijpen van de Witte Kaproenen onder leiding van Jan Yoens in 1368 stelde een einde aen „t werc van der niewer Leye”.

Deze tegenvaller weerhield Brugge niet om de beken binnen zijn machtsbereik in goede staat te houden. In 1367 ruimde Gillis Christiaen de watergang boven St.-Baafs: „den waterganc boven der stede vivere te Bueterbeke" ${ }^{60}$. Zoals men ziet, noemt de schrijver de beken boven Brugge, en soms ook de Leie, niet gauw met hun naam. In 1379 verschijnt een beeknaam. Matthijs de delver wordt betaald voor 150 roeden „,weerx gedelfs ghemaect an Bueterbeke ende an de beke van Tillegheem" 61 .

In hetzelfde jaar vernemen we tevens het eerste werk aan een brug. Ten gevolge van het verbreden en verdiepen van de Leie voldeed de oude houten brug te St.-Joris niet meer. De stad liet een volledig nieuwe stenen brug bouwen voor 2284 pd par.: ,van eenre stenine brucghe ghemaect in t ghedelf van der nieuwer Leye ieghen sinte Ioris kercke, ende van allen den stenen, calke ende alle andere stoffe diere toeghinc, al vulmaect up ghelevert bi rechter vorworden" 62 .

Eerst in 1390-91 zegt de schrijver duidelijk dat „de watergang boven de Stadsvijver" de Abdijbeek is. Pieter Dankaert, een aannemer van delfwer-

(55) Rek. Stad Brugge, 1316, fo $45 \mathrm{r}^{\circ}$.

(56) Rek. Stad Brugge, 1318-19, fo $38 \mathrm{r}^{\circ}$.

(57) Rek. Stad Brugge, 1360-61, fo $68 \mathrm{v}^{\circ}$.

(58) Rek. Stad Brugge, 1361-62, fo $57 \mathrm{r}^{\circ}$ en $\mathrm{f}^{\circ} 58 \mathrm{v}^{\circ}$.

(59) Rek. Stad Brugge, 1366-67, fo $44 \mathrm{r}^{\circ}$.

(60) Rek. Stad Brugge, 1366-67, f ${ }^{\circ} 61 \mathrm{r}^{\circ}$.

(61) Rek. Stad Brugge, 1378-79, fo $56 \mathrm{v}^{\circ}$.

(62) Rek. Stad Brugge, 1378-79, fo $56 \mathrm{v}^{\circ}$. 
ken, verricht het werk ,,van den waterganghe, commende van den nieuwen cloostre, te delvene ende te rumene van haghen ende van bramen, tote der Bueterbeke, lanc 1451 roeden, van elker roede 5 inghelsche, boven breet wesende 7 voete, ende in den bodem 2 voete". Langs de Abdijbeek werden zeven kleinere beken van een afvoerbuis voorzien: „van 7 buusen te makene ligghende in der stede waterganc, die nu niewelincx ghedolven es, commende van bi Varsenare in der stede vivere" ${ }^{63}$.

In hetzelfde jaar kwam ook de St.-Trudoleet aan de beurt om herdolven te worden. De Heer van Assebroek was bereid de watertoevoer naar Brugge te helpen bevorderen. Om die reden beloofde en gaf de stad een som geld „te hulpen der wateringhe" die de heere van Arsembrouc zal doen delven, commende in t minne watre" ${ }^{64}$. Uit deze en andere teksten blijkt dat de term Minnewater, niet alleen de waterkom bij het Begijnhof, aanduidde, maar ook de benedenloop van de Leie, waar de Kerkebeek en de Trudoleet uitmondden.

Er verschijnen mededelingen over bruggen. In 1393 herbouwt Jacop van Coppenholle twee bruggen op de Leie in hout: de Moerbrug en de Beernembrug ${ }^{65}$. In 1397 maakt Jan van Oudenaarde akkoord met de stad om de Steenbrug te herbouwen in arduin. Om aan de inwoners van Oostkamp ondertussen toch de mogelijkheid te geven om gemakkelijk de stad te bereiken, herstelde Brugge een houten brug over een beek, die volgens de tekst de Leiselebeek moet geweest zijn: ,,van eere houtiner brucghe van nieux te makene, staende neffens der Leye over eene beke commende van Sinte Michiels waert, omme over te gane ende te ridene allen lieden commende ter stede waert, mids dat de hoghe steenbrucghe te broken was" ${ }^{66}$.

De Trudoleet, ook geheten Watergang van Assebroek, wordt in 1399 nogmaals gedolven. Het werk begon bij de monding, waar de Kleine Steenbrug in de Kortrijkse Weg lag, en strekte 716 roeden stroomopwaarts tot een plaats in Assebroek, die we niet nader kunnen situeren: „,van den waterganghe te rumene ende te diepene van Orssembrouc, beghinnende ter cleenre steenbrucghe ende streckende tote up dicke slop bi Orssembrouc, den hiltewere" ${ }^{67}$.

In 1401 werkt Brugge in de Kerkebeek, ,den waterganc van der stede beghinnende ten minne watre ende streckende tote der corter brucghe". Over een afstand van $375 \mathrm{R}$ wordt de bedoelde waterloop gezuiverd van de waterplanten: „te roytene ende te zuverne". Verder was het nodig ,den vorseiden waterganc te verdelvene ende te verdiepene 62 roeden, duergaende drie voeten, mids dat hi verland was" 68 .

De herdolven Kerkebeek en Trudoleet brachten niet genoeg water. Daarom werden schepenen, ghesendt lanx de Leye tot Haeltre omme de ghebreke te doen repareren omme $t$ water te bet te commene ter stede waert". $\mathrm{Na}$ deze schouwing werd in twee gemeenten delfwerk verricht: 1. "ghewrocht

(63) Rek. Stad Brugge, 1390-91, fo $74 \mathrm{v}^{\circ}$ en $78 \mathrm{v}^{\circ}$.

(64) Rek. Stad Brugge, 1390-91, f $107 \mathrm{v}^{\circ}$.

(65) Rek. Stad Brugge, 1392-93, fo $59 \mathrm{r}^{\circ}$.

(66) Rek. Stad Brugge, 1396-97, fo $56 \mathrm{v}^{\circ}$.

(67) Rek. Stad Brugge, 1398-99, fo $65 \mathrm{r}^{\circ}$.

(68) Rek. Stad Brugge, 1400-01, fo $72 \mathrm{r}^{\circ}$ en $\mathrm{f}^{\circ} 74 \mathrm{r}^{\circ}$. 
t sint Ioris in distele an zekere waterganghe aldaer commende in de Leye, dewelke zeer verlant waren, daer zy in de Leye vallen, die te rumene, omme dat $\mathrm{t}$ water te bet commen soude mueghen te Brugghe waert”; 2. „van der stede waterganghe beghinnende bachten sint Truden clooster ende also streckende tot den Doledamme wel te vervaghene ende te diepene tot den ouden bodeme". Dit laatste werk was $486 \mathrm{R}$ lang ${ }^{69}$. Vermoedelijk wordt de Mazelbeek te Assebroek bedoeld.

Nog twee bruggen worden genoemd: 1. in 1402 ,,van eere steeniner brucghe van nieux te makene bi der ghemeener weede over der stede waterganc" ${ }^{70}$; 2. „van der brucghe, die de stede heift ghedaen maken bi Beverhoutsvelde, te erdene" ${ }^{71}$. We vermoeden dat de eerstgenoemde brug op de Trudoleet lag, en de tweede op de Mazelbeek.

Nadat de bijrivieren nog eens bijgewerkt waren, zag Brugge dat de Leie nog een groot gebrek vertoonde. Te Aalter stroomde het zo nodige water in de verkeerde richting! Op 27 september 1404 aanvaardde Pieter Dankaert het werk ,van eenen damme te scietene ende te makene dwers den ghedelve van der niewer Leye, in eene ieghenoode gheheeten de Thoolnare up $t$ heerscip van der Woestine, omme dat $t$ water van den velde ende riolen aldaar te bet zoude commen te Brucghe waert, ten behoude van der vaert, $\mathrm{t}$ welke al te Ghendwaert plach te lopene".

De aannemer moest de dam vier roeden breed maken, ,, nemende an beeden ziden $d$ erde up den barem van der Leye, $t$ welke der stede grond es" 72 . Hier past het wel de breedte van de Leie en van de twee dijken aan te geven. Pieter Bolle meet in 1507 een van de bermen. Bij deze gelegenheid noteert de ontvanger de volgende cijfers: „de zelve Leye binden alf maerte watre wijd 7 roeden, ende an elke zijde van der Leye $31 / 2$ roeden, comt in t gheheele 14 roeden" 73 .

De stad deed dikwijls beroep op de delvers van P. Dankaert. Ze waren bereid om: 1 . in 1410 de Kerkebeek 804 roeden ver te ruimen: ,van der stede waterganghe streckende van den minnewatre toter corterbrucghe te roytene ende te zuverne van den riede ende andren crude" ${ }^{74} ; 2$. in 1411 een sektor van de Leie te verdiepen: „van der stede watergang, die men heet de Leye, bi der Moerbrucghe te verdiepene" ${ }^{75}$.

In juli 1415 makt P. Dankaert akkoord om gans de waterweg van Assebroek tot de vesten te verdelven of te reinigen. Het werk bestond uit drie delen: 1. De Trudoleet te delven, beginnende te Assebroek ,ende also streckende te Brugghe waerd, also verre als de ghemeene weede lieght, toten ouden canten, 13 voeten wyt ten bodeme ende eenen voet diepere dan d ouden bodem”; 2. „,beghinnende van der vorseider ghemeenre weede ende also streckende te Brugghe waerd toter cleenre steenbrugghe den selven waterganc te roytene ende dat ute te doene metten wortelen"; 3.

(69) Rek. Stad Brugge, 1402-03, f $56 \mathrm{v}^{\circ}, \mathrm{f}^{\circ} 57 \mathrm{r}^{\circ}$ en $\mathrm{f}^{\circ} 80 \mathrm{r}^{\circ}$.

(70) Rek. Stad Brugge, 1401-02, fo $78 \mathrm{v}^{\circ}$.

(71) Rek. Stad Brugge, 1402-03, fo $56 \mathrm{v}^{\circ}$ en $58 \mathrm{r}^{\circ}$.

(72) Rek. Stad Brugge, 1404-05, fo $59 \mathrm{r}^{0}$.

(73) Rek. Stad Brugge, 1507-08, fo $96 \mathrm{r}^{\circ}$.

(74) Rek. Stad Brugge, 1410-11, fo $73 \mathrm{r}^{\circ}$.

(75) Rek. Stad Brugge, 1411-12, fo $62 \mathrm{r}^{\circ}$. 
„,van den waterganghe streckende van den minne water toter corter brucghe te delvene ende te diepene toten ouden bodeme ende toten ouden canten" 76 .

En op 24 augustus 1415 verklaarde Claes f Willems zich bereid ,te makene eene steeninbrucghe in de prochie zinte Michiels bi Tillegheem... ter plaetse,, die men heedt de cortebrucghe" 77 . Drie jaar later krijgt de beek te St.-Michiels weer zijn delfbeurt: ,den waterloop licghende bi sinte Michiels, de welke verlandt was, up ghedolven ende verdiept" 78 .

We zagen reeds dat P. Dankaert de Leie, van de vesten tot Moerbrug, in 1411 en 1415 herdolven heeft. Ook verder stroomopwaarts was de waterloop ,zeere verlandt" geraakt. Alaert Dankaert werkt in de zomer van 1419 om ,de Leye te verdelvene... beghinnende, omtrent 600 roeden verre, an gonzide der Moerbrucghe ende also upwaert streckende tote bi Bloumegheems brucghe" 79 .

De ontvanger van de stad noemt de hoofdwaterloop meestal Leie. Ook de voornaamste bijrivier, de Kerkebeek, wordt soms met de naam Leie, ofwel Kleine Leie, aangeduid. Dit laatste is duidelijk zodra we de volgende tekst van 1420 lezen: "ghewrocht an de voetbrucghe over de Leye voor sinte Michiels kerke" 80 .

Uit vele aangehaalde teksten heeft de lezer reeds lang begrepen dat Brugge zich inspande om zoveel mogelijk water bij te brengen. Maar het moest zuiver beekwater zijn, en geen vuil straatwater! In november 1421 werkte P. Dankaert ,ter Moerbrucghe an den barem van der Leye aldaer te hooghene, omme $t$ water van der straten in de Leye zinen loop te benemene" 81 .

Ook de volgende aanhaling wijst op het streven van Brugge. Tegelijk krijgen we de eerst, ons bekende, vermelding van de Rivierbeek: ,ghegheven te hulpen van zekeren ghedelve an eene beke bi Orscamp, t welke ghedelf ghemaect was ten orbore van der Leye, bi der welker de stede ghewatert es" 82

Bezorgden de beken boven Brugge veel werk en kosten aan de stad, ze schiepen soms een gans ander probleem. In zeer natte winters of in perioden met buitengewone regenval brachten ze te veel water ineens naar Brugge. Dan kon de Reie de watermassa niet dadelijk verwerken. De sluizen van het Minnewater en van de Boterbeek werden gesloten. De vestingsgracht met zijn twee dijken diende als kom om een deel van het overtollige water op te vangen. Aangezien ook de Leie van bermen voorzien was, zocht het water een uitweg door in St.-Michiels buiten de oevers van de beken te treden.

Het St.-Janshospitaal bezat te St.-Michiels de hofstede ten Briele. Dank zij dit feit vernemen we twee overstromingen in de genoemde parochie. De

(76) Rek. Stad Brugge, 1414-15, f f $^{\circ} 2 \mathrm{v}^{\circ}$ en $\mathrm{f}^{\circ} 53 \mathrm{r}^{\circ}$.

(77) Rek. Stad Brugge, 1414-15, fo $57 \mathrm{r}^{\circ}$.

(78) Rek. Stad Brugge, 1417-18, fo $75 \mathrm{v}^{\circ}$.

(79) Rek. Stad Brugge, 1419-20, fo $74 \mathrm{v}^{\circ}$.

(80) Rek. Stad Brugge, 1420-21, fo $60 \mathrm{v}^{\circ}$.

(81) Rek. Stad Brugge, 1421-22, f $\mathrm{f}^{\circ} 61 \mathrm{r}^{\circ}$.

(82) Rek. Stad Brugge, 1430-31, fo $53 \mathrm{v}^{\circ}$. 
pachter kreeg in 1404 afslag van zijn pacht: „ten tiden als t groote water cam naer paesschen, waer of dat hi hadde huutnemende groote scade" 83 . De tekst van 1437 echter is buitengewoon sprekend: „Arnoud Hebbin, ons pachtere ten briele, begheert grote gracie ende seicgt dat zijn coren ende zijn hoy met allen verdronken heift gheweist twee iaer lanc van den groten watere, dat die van Brucghe buten ghehouden hebben". En inderdaad hij krijgt vermindering voor de jaren 1436 en 1437 „omme dat die Brucghe alle den voorseiden tyd gheduerende t water buten zo hoghe hilden" 84 .

In 1430 gaf de Waardammebeek geen voldoening meer. Op 17 juli werd Jacop Zweertvagher ,ghesonden zuutwaerd upten waterganc, die comt van Thorout, van Ruddervoorde ende van Waerdamme, ende voort tot in de Leye omme $t$ overziene $t$ ghebrec van den ghedelve" ${ }^{85}$. In de volgende jaargangen vermeldt de ontvanger echter geen delfwerk in de Waardammebeek.

Toch kon Brugge, ondanks zijn niet aflatende inspanningen, niet verkrijgen dat de watertoevoer van boven in staat was om de voortschrijdende verlanding van het $Z$ win tegen te gaan. Men kon zelfs de sluis te Damme niet vrij houden van slib. De Reie moest regelmatig uitgebaggerd worden. Al deze gebreken zagen de acht notabelen van Brugge, die in 1471 de vaarweg van de stad naar Sluis schouwden. Daarna reisden ze langs de Leie om "de ryolen, grachten, vivers ende andere wateringhe suwerende in de Leye", te bekijken, en om na te gaan hoe "de voorseide wateringhe scoone te makene, ten fyne dat men $t$ zomertyden hier binder stede schoon ende varsch watre mochte hebben" 86 .

De stad heeft ingegrepen door aan de bevolking rond de Leie opdracht te geven de waterlopen van de streek te ruimen. Dit leren we uit de post: „Betaelt van zekeren kercgheboden te doen doene in diversschen prochyen ende kerken gheleghen omtrent Brucghe by zekeren dienaers ende officiers, ten fyne dat elc rumen ende scoone maken zoude de grachten ende waterloopen, die elc van ouden tyden hadde suwerende in de brucsche Leye" 87 .

De oproep van het stadsbestuur heeft weinig succes gekend. Immers op 12 augustus 1473 hielden een groot aantal vooraanstaanden een vergadering bij de Heer van Gruuthuse ,omme raet ende advys $t$ hebbene hoe men diverssche ryolen, grachten ende andere waterynghen, die wylen suweirden in $t$ minnewatre, ende nu verlant ende verstopt zijn, die weder ghecryghen zoude suwerende in $t$ voorseide minnewatre ende veste van deser stede, ten fyne dat men $t$ verssche watre van boven mochte hebben in de voorseide vesten van deser stede, $t$ somerdaechs alzo wel als $s$ winterdaechs" 88 .

Als gevolg van de genoemde bespreking trokken schepenen en een landmeter op 5 december 1473 erop uit „omme te bezoukene tusschen Brugghe ende Ghent de watren aldaer gheleghen, of men daer mede altoos varsch

(83) St.-Janshospitaal, Rek. nr. 87, 1403-04, f ${ }^{\circ} 79 \mathrm{r}^{\circ}$.

(84) St.-Janshospitaal, Rek. nr. 136, 1437-38, fo $115 \mathrm{v}^{\circ}$; nr. 137, 1438-39, fo $85 \mathrm{r}^{\circ}$.

(85) Rek. Stad Brugge, 1430-31, fo $66 \mathrm{r}^{\circ}$.

(86) Rek. Stad Brugge, 1470-71, f ${ }^{\circ} 68 \mathrm{v}^{\circ}$.

(87) Rek. Stad Brugge, 1470-71, f ${ }^{\circ} 131 \mathrm{v}^{\circ}$.

(88) Rek. Stad Brugge, 1472-73, f $134 \mathrm{v}^{\circ}$. 
loopende watre van buten hier binnen deser stede zoude mueghen hebben" 89 .

In het laatste kwart van de $15 \mathrm{e}$ eeuw geven de stadsrekeningen geen mededelingen over aktiviteit vanwege Brugge in het stroomgebied van de Leie. In 1508 trachtte de stad haar zeggenschap over het water uit te breiden naar het oosten en naar het zuiden. De ontvanger noteert dat afgevaardigden ,ghereyst zyn ten witten moere by Maldegheem, ter Woestyne, te Thoroult ende daer omtrent omme te visiteren de loopen van den wateren vallende naer dese steden, ende ooc die elders vallen ende cours nemen, ofte men die zoude moghen beleeden erwaerts vallende" ${ }^{90}$.

In 1523 besloot Brugge de loop van het water in de Leie te kontroleren door twee sluisjes te plaatsen: ,beede de rabbaten in de zuudleye”; werklieden werkten ,ter Moerbrugghe ende Ghevaertsbrugghe omme t stellen van den selven rabbaten" ${ }^{91}$. De stad heeft daarna een sluiswachter aangesteld. In 1539 woonde de ,rabathoudre van der Zuudleye” bij Gevaertsbrug.

De Rivierbeek wordt niet dikwijls vermeld, maar toch in 1534 , in $t$ visiteren van den waterloope streckende van boven Wynghene tot binnen dese stede" ${ }^{22}$. In 1538 heeft Simon Huusman de wateren rond het Minnewater gereinigd: „ten minnewatere streckende alzo verre, alsmen van der brugghe de Leye zien mach".

In het laatstgenoemde jaar werkte men aan twee bruggen over de Kerkebeek. De stad betaalde een som geld aan de ,ghelande omtrent den waterloop streckende van deser stede naer sinte Michiels, Thilleghem ende Loppen... omme $t$ maken van eene nyeuwe brugghe over den zelven waterloop by sinte Michiels kercke, ende hooghen van der brugghe ligghende in de strate over den zelven waterloop leden sint Sebastiaens capelle" ${ }^{93}$.

Op 26 april 1540 reisde een belangrijk gezelschap langs de Leie. Burgemeester Guy de Baenst, vier schepenen, de twee tresoriers, een greffier en een pensionaris waren ,visiterende de Leye metter brugghen daerover ligghende, beghinnende van deser stede totten nyeuwen damme by der Wostine binder prochie van Aeltre" 94 .

$\mathrm{Na}$ deze schouwing ging men aan het werk op de Leie. Er zal een rabat gesteld worden ,by der waelbrugghe”. De Zuid-Leie werd gereinigd van de Moerbrug tot de Waalbrug. Verder stroomopwaarts was het nodig ,de zelve Leye te doen delvene totten ouden canten enden ouden boom, totter Lendebrugghe". Anthuenis Slembrouck bouwde een brug over de Leie "ter plaetsen ghenaemt ter Lendebrugghe" ${ }^{95}$.

In 1541 werd aandacht besteed aan de Rivierbeek, zelfs vanwege kommissarissen van de keizer. De beek wordt omschreven als volgt: „den waterloop streckende van der Moerbrugghe naer Winghene"; „t rivierkin vallende van Winghene in de Leye deser stede". In juni 1542 trok een tre-

(89) Rek. Stad Brugge, 1473-74, fo $64 \mathrm{v}^{\circ}$

(90) Rek. Stad Brugge, 1507-08, fo $71 \mathrm{r}^{\circ}$.

(91) Rek. Stad Brugge, 1522-23, fo $105 \mathrm{r}^{\circ}$.

(92) Rek. Stad Brugge, 1533-34, f $63 \mathrm{r}^{\circ}$.

(93) Rek. Stad Brugge, 1537-38, fo $68 \mathrm{v}^{\circ}$ en $\mathrm{f}^{\circ} 69 \mathrm{r}^{\circ}$.

(94) Rek. Stad Brugge, 1539-40, fo $60 \mathrm{r}^{\circ}$.

(95) Rek. Stad Brugge, 1539-40, fo $60 \mathrm{v}^{\circ}, \mathrm{f}^{\circ} 63 \mathrm{v}^{\circ}$ en $\mathrm{f}^{\circ} 68 \mathrm{r}^{\circ}$. 
sorier langs ,de Zuudleye van der stede van Brugghe naer de Moerbrugghe, van daer naer de Ghevaersbrugghe, van daer naer de Walbrugghe, ende noch uppewaerts totten hende van de nieuwen ghedelve" ${ }^{96}$.

Ondanks het delfwerk van 1540 vervulde de Zuid-Leie in droge zomers toch niet de taak, die de stad Brugge van haar verwachtte. Op 14 augustus 1545 trokken schepenen ,tot Haeltre lancx der Brugscher Zuudtleye” om een middel te vinden „omme te bet veersch waetere binnen dese stede te ghecryghene" ${ }^{97}$. Ten gevolge van dit bezoek werden in 1546 werken uitgevoerd. Er werden dammen gelegd waar de oevers van de Leie te laag waren om het water binnen de bedding te houden: op 21 juli naar „de Zuutleye tot Zotschoore (te Oedelem) omme te visiterene zekere damme, die men aldaer in diversche plaetsen maecte ieghen de neiringhe, omme gheen waetere van der zelver Leye te verliesene, nemaer ter stede waert te zendene" 98.

$\mathrm{Na}$ de winter, op 25 april 1547, reizen werkopzieners van Brugge langs gans „de Zuudtleye streckende naer sint Jooris ten distele ende voorts naer den Brugschen dam" 99, om de loop van het water te bezien. Die schouwing was nodig, want in de volgende zomer klaagde men te Damme over moeilijkheden met het doorspoelen van de Speie ,midts $t$ cleen upperwaetere by der droochte" ${ }^{100}$. Dan maar nog eens de bedding van de Leie uitgraven!

Het jaar 1548 meldt twee werken ten voordele van de Brugse Leie: 1. „zuveren van een waeterloop vallende in de Zuutleye beneden Zotschoore commende van Hulsterloo" 101 ; 2. De Stad kocht een perceel van ong. 2,5 ha, gelegen te Beernem bij de Walbrug langs de Leie „omme aldaer een haerc van der zelve Zuudtleye te makene, ende de vaert van dien te vrydene ende goedt te makene" ${ }^{102}$. Indien het woord ,,aerc" betekent bocht, dan kunnen we de laatste tekst best begrijpen als volgt: het aangekochte perceel diende om een bocht van de Leie in te korten; de oude bedding werd van de nieuwe afgezonderd.

Tenslotte vermelden we nog dat de speihouder van de Brugse Leie, Meeus van Hoeke, in 1550 de rabatten herstelde "ter ghevaers ende walbrugghen" en aldaar ",de vaert" deed verdiepen. Hij werd ook betaald voor het ,,vermaken van waterloopen" en het ,verlegghen van beken in de Leye vallende" ${ }^{103}$. De termen ,speyhoudere" en „vaert" schijnen erop te wijzen dat de Zuid-Leie ook als vaarweg gebruikt werd.

We menen dat het verhaal over de Brugse Leie en zijn stroomgebied hier kan afgesloten worden. De vele teksten uit de Brugse stadsrekeningen hebben voldoende aangetoond hoever dit waterbekken zich uitstrekte. Brugge heeft vooreerst het zeggenschap over he waternet van de Zuid-Leie verworven en vervolgens gekontroleerd door middel van sluizen en rabatten. De

(96) Rek. Stad Brugge, 1541-42, fo $61 \mathrm{r}^{\circ}$ en $\mathrm{f}^{\circ} 71 \mathrm{r}^{\circ}$.

(97) Rek. Stad Brugge, 1544-45, fo $75 \mathrm{v}^{\circ}$.

(98) Rek. Stad Brugge, 1545-46, fo $75 \mathrm{v}^{\circ}$.

(99) Rek. Stad Brugge, 1546-47, fo $104 \mathrm{r}^{\circ}$.

(100) Rek. Stad Brugge, 1546-47, fo $74 \mathrm{r}^{\circ}$.

(101) Rek. Stad Brugge, 1547-48, fo $75 \mathrm{r}^{\circ}$. De Flou situeert het leengoed Hulstlo ten zuiden van de Leie.

(102) Rek. Stad Brugge, 1548-49, fo $104 \mathrm{r}^{\circ}$.

(103) Rek. Stad Brugge, 1549-50, fo $77 \mathrm{r}^{\circ}$. 
stad spaarde noch geld noch moeite om zoveel mogelijk water uit de Zandstreek aan te trekken, niet alleen omwille van de behoefte aan vers water in de stad zelf, maar vooral omwille van de dringende noodzaak de vaarweg tussen Brugge en de zee door te spoelen. Spijt alle werk en alle onkosten was het stroomgebied van de Zuid-Leie niet in staat voldoende water te leveren om de verslibbing van de Reie en van het Zwin blijvend tegen te gaan. Thans blijft van het befaamde Zwin slechts een kleine kreek over.

\section{BIBLIOGRAFIE}

Amerijckx J., Hoe ontstonden de Belgische Zeepolders? Wet. Tijdingen, nr. 6, p. 241-252 (1960).

Astaes S., Het waterwegennet ten noorden van Brugge in de XIe tot de XIVe eeuw, Handelingen Maatschappij Geschiedenis en Oudheidkunde Gent, deel 18, p. 317 (1964).

Boterberghe R., Historische Geografie van het IJzerestuarium, Hand. Gesch. Gent, deel 16, p. 83 (1962).

Coornaert M., Het land acbter de Evendijk, Rond de Poldertorens, 5e jg. nr. 4 (1963). Koudekerke-Heist, De topografie en de toponimie van Heist-aan-zee tot omstreeks 1860 (1965).

De zeewering van de Oudemaarspolder, R.d.P. 8e jg. nr. 2 en 3 (1966).

De Keyzer R., De ontwatering ten noorden van Brugge, R.d.P. 6e jg. nr. 4 p. 118143 (1964).

Gottschalk M., Historische geografie West-Zeeuws-Vlaanderen (1955).

Gysseling M., Toponymie van Oudenburg (1950).

Verhulst A., Historische geografie van de Vlaamse kustvlakte tot omstreeks 1200 , Bijdragen voor de geschiedenis der Nederlanden, deel 14, p. 1-137 (1959).

Het iandschap in Vlaanderen in bistorisch perspectief, Ned. Boekhandel (1966). 